\title{
Bioelectrochemical Systems for Groundwater Remediation: The Development Trend and Research Front Revealed by Bibliometric Analysis
}

\author{
Wei Li ${ }^{1,2,3, * \mathbb{D}}$, Xiaohong Chen ${ }^{1, * \mathbb{D}}$, Linshen $\mathrm{Xie}^{2}{ }^{2}$, Zhao Liu ${ }^{4}$ and Xiangyun Xiong ${ }^{5}$ \\ 1 School of Civil Engineering, Sun Yat-Sen University, Zhuhai 519082, China \\ 2 Shenzhen Academy of Environmental Sciences, Shenzhen 518001, China \\ 3 MOE Key Laboratory of Groundwater Circulation and Environmental Evolution, China University of \\ Geosciences (Beijing), Beijing 100083, China \\ 4 Information Engineering Department, Space Star Technology Co., Ltd. (SST), China Aerospace Science and \\ Technology Corporation, Beijing 100095, China \\ 5 Shenzhen Environmental Monitoring Center, Shenzhen 518049, China \\ * Correspondence: liwei@meeb.sz.gov.cn (W.L.); eescxh@mail.sysu.edu.cn (X.C.); \\ Tel.: +86-0755-2598-0351 (W.L.); +86-020-8411-5901 (X.C.)
}

Received: 20 June 2019; Accepted: 19 July 2019; Published: 24 July 2019

\begin{abstract}
Due to the deficiency of fresh water resources and the deterioration of groundwater quality worldwide, groundwater remedial technologies are especially crucial for preventing groundwater pollution and protecting the precious groundwater resource. Among the remedial alternatives, bioelectrochemical systems have unique advantages on both economic and technological aspects. However, it is rare to see a deep study focused on the information mining and visualization of the publications in this field, and research that can reveal and visualize the development trajectory and trends is scarce. Therefore, this study summarizes the published information in this field from the Web of Science Core Collection of the last two decades (1999-2018) and uses Citespace to quantitatively visualize the relationship of authors, published countries, organizations, funding sources, and journals and detect the research front by analyzing keywords and burst terms. The results indicate that the studies focused on bioelectrochemical systems for groundwater remediation have had a significant increase during the last two decades, especially in China, Germany and Italy. The national research institutes and universities of the USA and the countries mentioned above dominate the research. Environmental Science \& Technology, Applied and Environmental Microbiology, and Water Research are the most published journals in this field. The network maps of the keywords and burst terms suggest that reductive microbial diversity, electron transfer, microbial fuel cell, etc., are the research hotspots in recent years, and studies focused on microbial enrichment culture, energy supply/recovery, combined pollution remediation, etc., should be enhanced in future.
\end{abstract}

Keywords: groundwater; bioelectrochemical systems; remediation; citespace

\section{Introduction}

Groundwater, representing c. $97 \%$ of the fresh water resources of the earth (excluding those locked, such as the ice in the polar regions) [1] is vital to the sustainable development of the society and economy all over the world, especially for the residents in the arid and semi-arid regions who consider groundwater as their major domestic water source [2-5]. However, great concern has been raised about the deterioration of groundwater quality related to rapid industrialization and civilization in the last decades [2,6-9], and groundwater pollution events caused by human activities (the application of fertilizer and manure [10-13], the discharge of industrial effluents [14-18], and the leakage of landfill 
sites $[19,20]$ have been reported round the world. Thus, the invention and implementation of groundwater remedial technologies is a hotspot issue for environmental experts nowadays [21-24], and numerous technologies involving physical, chemical, physical-chemical, biological and biochemical aspects have been invented and applied [25,26], e.g., the pump and treat method (contaminated groundwater is pumped by abstracted wells and further treated) [27-30], permeable reactive barriers (a subsurface barrier is constructed by reactive materials, and the polluted groundwater is remediated during flowing through the barrier) [31-35], soil vapor extraction (a vacuum is applied to the vadose zone to induce the controlled flow of air and remove volatile and some semi-volatile organic contaminants) [36-38], and monitored natural attenuation (based on efficient monitoring, pollutants are degraded to acceptable levels by natural physical, chemical and biochemical reactions) [39-41].

With continued innovation and advances in groundwater remedial technologies, some researchers have focused on novel technologies that are more efficient, sustainable and cost-saving [42-45]. Among these, bioelectrochemical systems (BESs) have remarkably emerged in the last two decades [25,46-53]. BESs can be defined as microbial electrochemical systems in which electrochemically active microorganisms act as catalyzers for anode and/or cathode reactions [25,42]—specifically, the electro-active microorganisms, the electrodes, and the possible electron donor/acceptors (groundwater pollutants) consist of an electrical circuit through which the electron is transferred by the electro-active microorganisms while the pollutants are oxidized/reduced [25,54-56], which means that both oxidation and reductions can occur at the anode and the cathode, respectively $[25,49,57]$. According to the above fundamental of microbial electrochemistry, multiple systems/devices have been invented by the applied researchers and engineers from a concept to a practice, namely the microbial fuel cell (MFC, a system/device with microbes that can generate electricity while using hydrocarbons as the carbon source) [58-60], the microbial electrolysis cell (MEC, a micro-chemical system/device that needs power source to operate/enhance the bioelectrochemical process) [42,61], the microbial desalination cell (MDC, a system/device that desalinates water using electricity generated by the exoelectrogenic microorganisms from the degradation of organic matter) [62-64], and the biogeobattery (an underground system that electro-active microorganisms combined with conductive minerals crossing the water table transports electrons from the anodic oxidation domains at depth (under the water table) to the cathodic reduction domains near the surface) [65-67], and which are studied for groundwater remediation of variable pollutants, such as nitrate $[49,57,68,69]$, perchlorate $[59,70,71]$, arsenic [72-74], hexavalent chromium [75], vanadium [75-77], uranium [78-81], cadmium [25,82] and aromatic compounds [58,83,84].

Compared with conventional remedial technologies, BESs have unique advantages on efficiency, flexibility and cost-saving [51,85-87]. For instance, phenanthrene and benzene reduction experiments conducted by Adelaja et al. [58] demonstrated that the in-situ degradation efficiency of petroleum hydrocarbons using an MFC could exceed $90 \%$ at a hydraulic retention time of 10 days, and the system showed the flexibility to adapt to shock substrate concentrations loading. Morris and Jin [88] designed a two-cell MFC with an extended proton bridge for the physical separation of the anode and cathode chambers to simulate groundwater hydrocarbon remediation, and the results indicated that the extended proton bridge, acting as a non-exhaustive source of terminal electron acceptor, could be a less expensive alternative to conventional groundwater bioremediation which uses costly oxygen releasing compounds for its electron acceptor supply. However, in the knowledge of the authors, most of the studies of BESs for groundwater remediation have been at the lab-experiment scale at the present stage, and they have mainly focused on the invention and performance testing of the systems/devices for the reduction of various pollutants in synthetic groundwater [25,42]. Research analyzing the development and evolution of this topic is rare, and no previous research has conducted comprehensive analysis in this field that can systematically reveal the aspects, including the co-authors, the most published countries, organizations, funding sources, journals, keywords/burst terms and visualize these results, which can offer insights into the changing and development trend of BESs research, and it is of great significant to the researchers for a further understanding of the orientation of BESs for future study and application. 
In the context of current needs, a bibliometric analysis of BESs for groundwater remediation was conducted in this study to investigate and visualize the relationship of authors, published courtiers, organizations, funding sources, and journals, and to detect the development trends of this topic with network maps of keywords and burst terms. The results of this study are helpful for obtaining more accurate information of the trajectory and research front in this field, and they serve as indicators for research advancement.

\section{Data Acquisition and Methods}

\subsection{Data Description}

The original data analyzed in this study were downloaded from the database of Web of Sciences Core Collection (Sciences Citation Index expended (SCI-expended) and Social Sciences Citation Index (SSCI)), considering the most important and frequently used scientific databases in all fields [89,90], and the searching timespan was set as the last two decades (from 1999 to 2018). To collect all publications related to BESs for groundwater remediation, the search formula was set as TS (searching topics) = (groundwater OR aquifer) AND TS = (bioelectrochem* OR bio-electrochem* OR BES OR bioelectro* OR microbial electro* OR biolo* electro* OR bioelect* OR microbial fuel cell OR biogeobattery). The results were restricted for all document types in English. Finally, 1729 publications met the criteria, the full record and cited references were exported for further analysis.

\subsection{Scientometrics Analysis Method}

The scientometrics analysis in this study was conducted by CiteSpace V, a bibliometric visualization and analysis software developed by Dr. Chaomei Chen of Drexel University based on Java [91]. Citespace can analyze the basic information of documents in a time-phased manner. The publications and citation of the literature were statistically analyzed, and the literature information in the retrieval period of a certain field was displayed in the form of a network map according to different cutting and splicing methods, reflecting the basis or front of the research field. In recent years, Citespace has been widely used in the fields of informatics, life sciences, technical sciences, and management. [89,91,92].

Considering the cited literature in a certain research field as the intellectual base, the citing literature represented the relative research front, and, thus, the overall research situation in this field can be generalized from a research front to an intellectual base. The research front can further be reflected by a set of keyword/term that evolved and mutated over time (generally a sudden increase in frequency of occurrence). Therefore, the core idea of Citespace is to identify this development and mutation trend from literature information and to explore and analyze research fronts in a certain research field according to mutation detection and cluster analysis [91,93]. In the specific operation, the intellectual base could visualize, for example, the number of publications and citations of different countries, research institutions, journals, and authors. The mutation detection and quotation of keyword/term can also be carried out on the research front, and a cluster analysis of the keyword/term explored the hot issues at the forefront of the research in this field.

In the network maps produced by Citespace, the color from blue to red indicates the time slice from the begin to the end, and each node in the figure represents a certain type (author, institution, country, term, keyword, source, category, reference, cited author, cited journal, article, grant and claim), with the number of frequency/accumulated citations illustrating by colorful tree rings and the colorful lines between the nodes represent the year of first co-occurrence/co-citations. Moreover, pivotal nodes in the network maps were recognized with high betweenness centrality and are highlighted with a purple ring. The betweenness centrality $\left(B C v_{i}\right)$ is defined as follows [90]:

$$
B C v_{i}=\sum_{p \neq i \neq q} \frac{t_{p q}^{i}}{T_{p q}}
$$


where $T_{p q}$ is the number of shortest paths from $v_{p}$ to $v_{q}$ and $t_{p q}^{i}$ is the number of shortest paths from $v_{p}$ to $v_{q}$ that pass though $v_{i}$. At the document level, the betweenness centrality is a valid metric to measure the importance of each document in a co-citation map.

\section{Results}

\subsection{Characteristics of the Publications of BESs for Groundwater Remediation}

Figure 1 illustrates variable document types of the yearly and total publications related to BESs for groundwater remediation from 1999 to 2018, and a rapid development trend was revealed by the number of yearly publication that continuously increased from 34 in 1999 to 151 in 2018. Articles were the dominant type of publication, accounting for about $94 \%$ of the total publications, followed by papers, reviews and other types of publication (book chapter, editorial material, meeting abstract and retracted publications), which made up the other $6 \%$. The cumulative publications showed a straight increasing trend-in particular, the cumulative publications from 2009 to 2018 were approximately threefold of that from 1999 to 2008, suggesting more scholars were focused on this topic in the most recent decade.

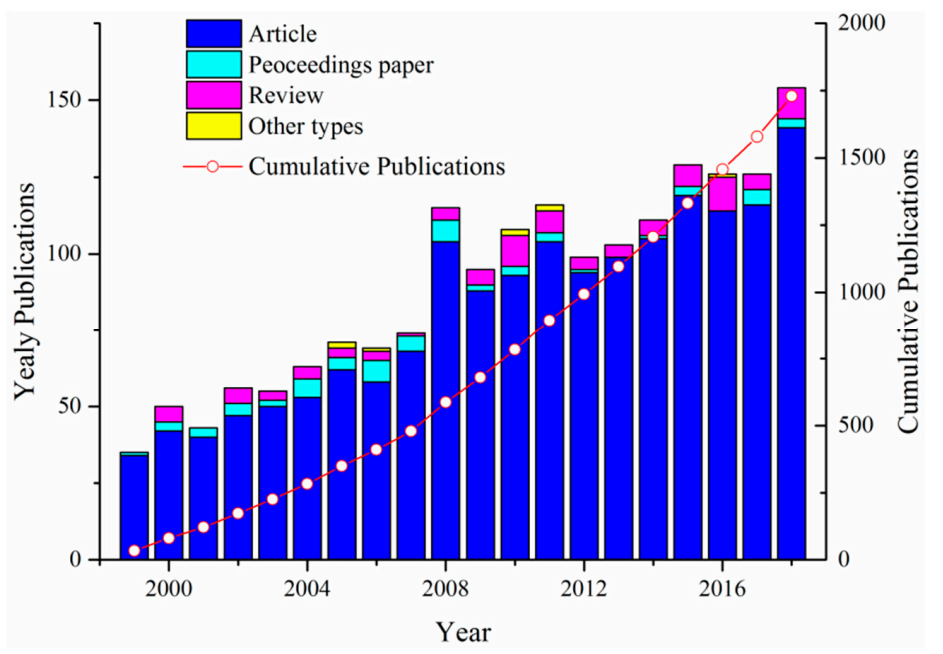

Figure 1. Quantitative characteristics of the publications of bioelectrochemical systems (BESs) for groundwater remediation during 1999-2018.

\subsection{Published Countries, Organizations and Funding Sources Analysis}

The searching results indicate that over 40 countries have published research achievements on this topic, while the top 10 countries of yearly publications are as follows: USA, China, Germany, Canada, England, Italy, Japan, France, Spain and Switzerland. These 10 counties have dominated the research on this topic, as their publications occupy over $95 \%$ of the total publications. The yearly and cumulative publications of all the countries mentioned above show a fluctuating increase over time (Figure 2). For instance, USA published 21 articles in 1999 and 44 in 2018, while the number of its maximum yearly publications was 54 in 2011. USA has contributed most of the publications on this topic among the world; in 2000, its publications accounted for $76 \%$ (highest in the period of 1999-2018) of the total publications of the top 10 countries. However, with the development of research in other countries, the publication proportion of USA among the top 10 countries has constantly decreased over time (70\% in 1999 and $25 \%$ in 2018), and the annual growth rates of the publications of China, Germany and Italy were $52 \%, 32 \%$, and 31\%, respectively (2009-2018). 


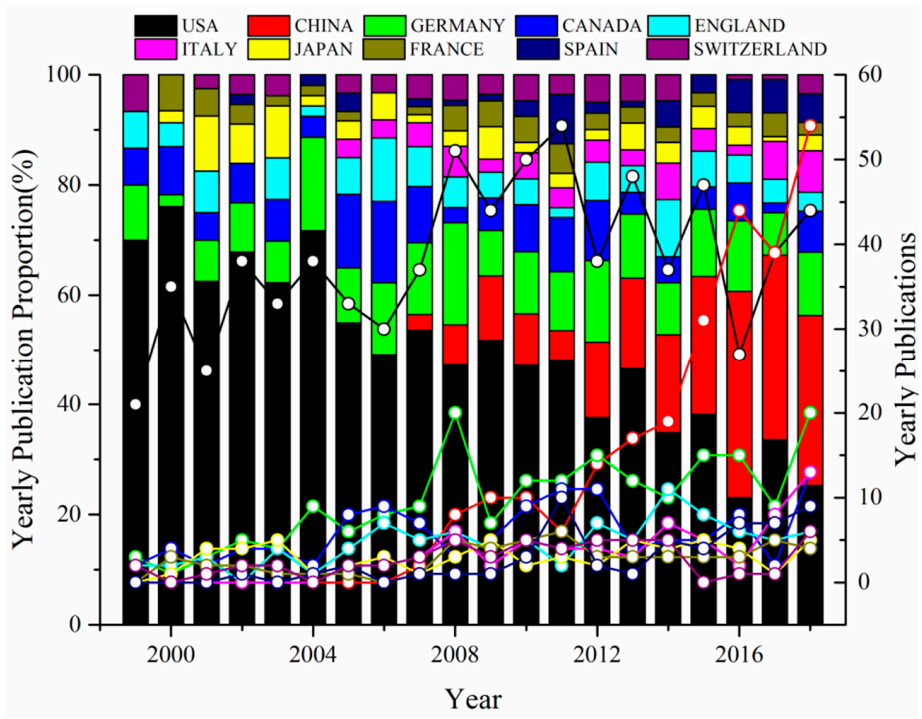

Figure 2. Characteristics of the top 10 publishing countries of BESs for groundwater remediation during 1999-2018.

Figure 3 depicts the characteristics of the publications and the co-citation of the productive organizations. The institutes with large number of publications were mainly the national research institutes and universities such as University of Massachusetts, University of California Berkeley, Pacific Northwest National Laboratory, which produce constantly and had the largest cumulative publications in the time slice. It should be noted that the number of publications of some institutes showed explosive growth-these are highlighted by the purple rings, indicating the research development of these institutes in this field, such as Oak Ridge National Laboratory, US Geology Survey and Chinese Academy of Sciences.

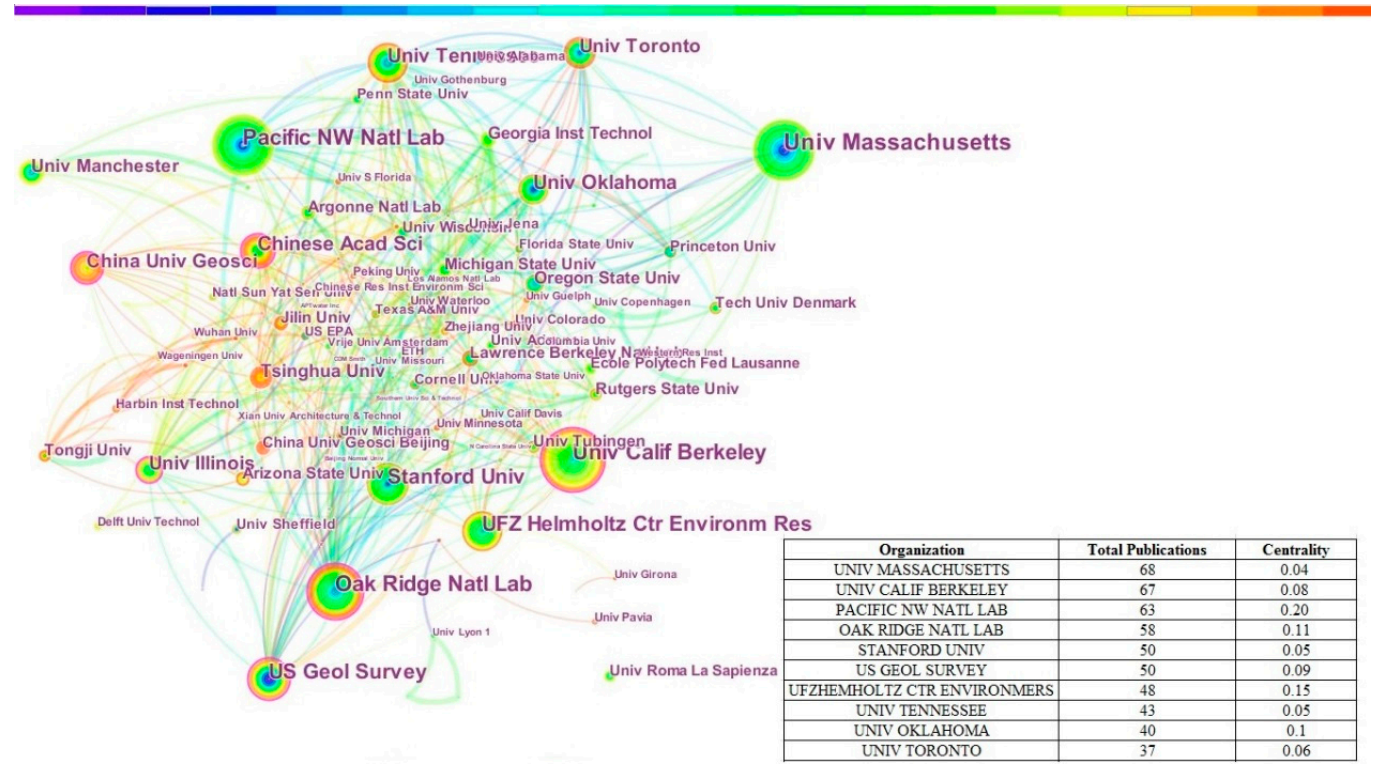

Figure 3. The network map of the productive organizations of BESs for groundwater remediation during 1999-2018. The colorful line bar in the top represents the total time slice from 1999 to 2018 (each color represents on year, similarly hereinafter), each productive organization is represented by a tree ring node (such as US Geol. Survey at the bottom of the figure), and the size of the node is proportional to the number of publications. The lines between the nodes represent co-publication, and the color of the tree rings and lines correspond to the line bar. The table on the right summarizes the top 10 productive organizations with their number of publications and the betweenness centrality. 
The funding sources were important for investigating potential research purposes and to deduce if the research was predominated by researchers or the funding organizations. The results obtained by Citespace $\mathrm{V}$ indicate that 70 funding sources were recorded with a total citation number of 458 (the network map is shown as Figure 4), most of which were national science fund and research councils such as National Natural Science Foundation of China, National Science Foundation (USA), and Natural Environment Research Council (UK). No commercial funding was detected, suggesting that the research of BESs for groundwater remediation was mainly led by the scientists in this field based on academic interests. According to the nationality, the funding sources can roughly be classified belonging to USA, China, and other countries. The number of funding sources of USA and China account for about $50 \%$ of the total, and which is in agreement with the results of the publishing countries mentioned above. National Natural Science Foundation of China was the most cited funding source, with a total citation number of 131-which is about four times of the second one (Fundamental Research Funds for the Central Universities, China).

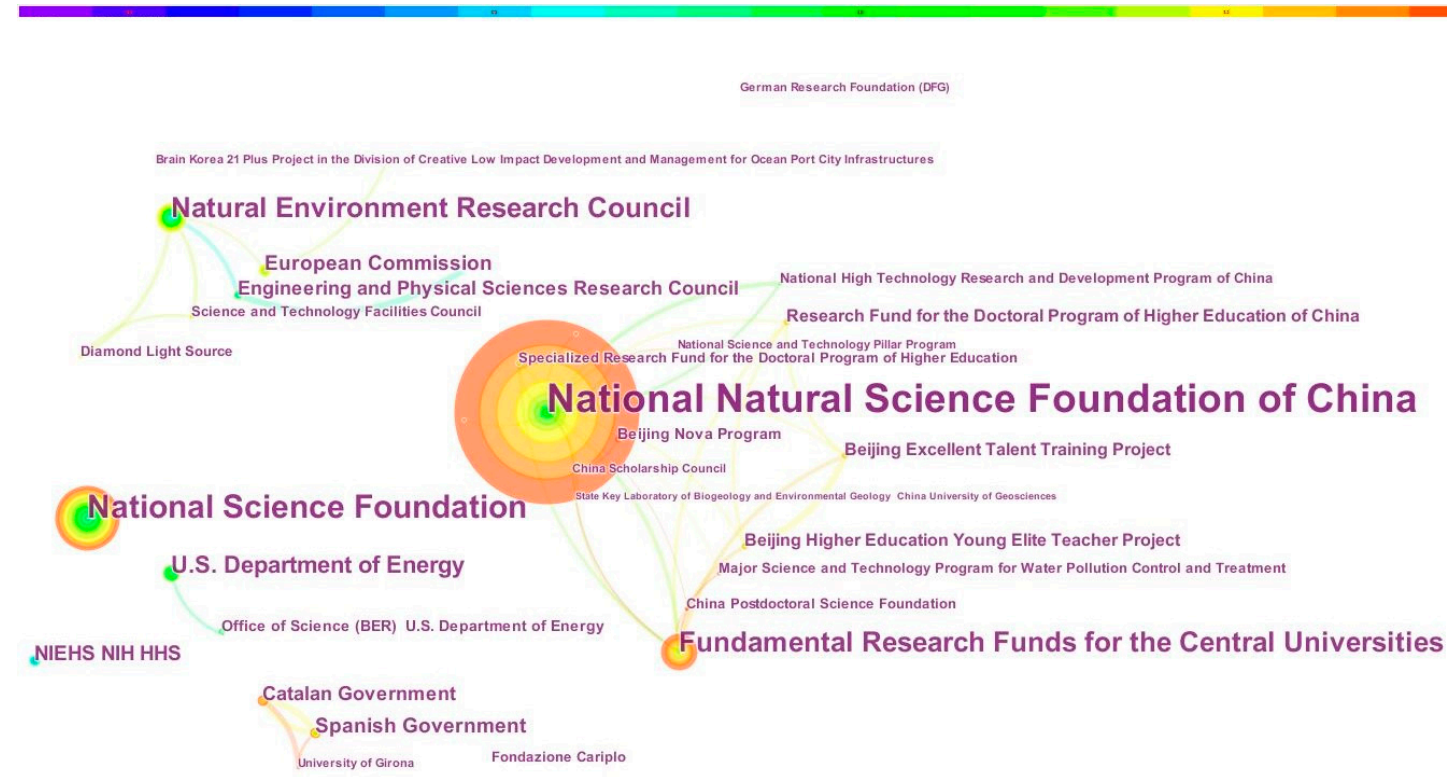

Figure 4. The network map of the funding sources of the publications of BESs for groundwater remediation during 1999-2018.

\subsection{Published Journals and Authors Analysis}

The investigation of the publishing journals and authors was an efficient approach to explore the research field. According to the citation report by Web of Science, there are 352 journals of 48 research areas (environmental sciences ecology, engineering, water resources, biotechnology applied microbiology and microbiology, etc.) that have published related achievements in this field during 1999-2018, and the top 10 frequently publishing and cited journals (summarized in Table 1) account for $36 \%(622 / 1729)$ of the total publications and $47 \%$ (27022/58056) of the total citations, most of which are the top journals of quartile in the category with high impact factors, such as Environmental Sciences $\mathcal{E}$ Technology, Applied and Environmental Microbiology, and Water Research, thus indicating the research of BESs for groundwater remediation has attracted much attention of the experts in a broad research field. 
Table 1. Statistical results of the top 10 publishing and cited journals of BESs for groundwater remediation during 1999-2018.

\begin{tabular}{ccccc}
\hline No. & Journal & $\begin{array}{c}\text { Total } \\
\text { Publications }\end{array}$ & $\begin{array}{c}\text { Sum of } \\
\text { Times Cited }\end{array}$ & $\begin{array}{c}\text { Journal IF (2018)/Quartile } \\
\text { in Category }\end{array}$ \\
\hline 1 & ENVIRON. SCI. TECHNOL. & 163 & 8004 & $7.149 / \mathrm{Q} 1$ \\
2 & APPL. ENVIRON. MICROB. & 85 & 5650 & $4.077 / \mathrm{Q} 1$ \\
3 & WATER RES. & 71 & 3143 & $7.913 / \mathrm{Q} 1$ \\
4 & J. CONTAM. HYDROL. & 53 & 2051 & $2.65 / \mathrm{Q} 2$ \\
5 & BIORESOUR. TECHNOL. & 52 & 1115 & $6.669 / \mathrm{Q} 1$ \\
6 & GEOCHIM. COSMOCHIM. ACTA & 45 & 2273 & $4.258 / \mathrm{Q} 1$ \\
7 & GEOMICROBIOL. J. & 44 & 1421 & $1.609 / \mathrm{Q} 3$ \\
8 & CHEMOSPHERE & 38 & 774 & $5.108 / \mathrm{Q} 1$ \\
9 & J. HAZARD. MATER. & 38 & 1519 & $7.65 / \mathrm{Q} 1$ \\
10 & FEMS MICROBIOL. ECOL. & 33 & 1072 & $4.098 / \mathrm{Q} 2$ \\
\hline
\end{tabular}

The productive authors and their publications in this field were investigated by Citespace V with the analysis results of the 1729 publications and their references relating to BESs for groundwater remediation. The authors with five or more publications and fifty or more cited are shown in Figure 5. As mentioned above, the characteristics of authors are illustrated by tree rings, of which the size represents the amount of publications/citation of one author and the color of the tree ring and the lines represent the year of publication/citation or co-citation. It was clearly revealed by the network map that authors tend to form research groups and develop cooperation and research groups usually consist of two or more core authors. For instance, the group of Lovley D.R., Williams K.H. and Long P.E. et al. produced the largest amount of publications (96) in this field, followed by the group of Criddle C.S., Wu W.M., and Hazen T.C. et al., the group of Aulenta F., Majone M. and Papini M.P. et al., the group of Feng C.P., Zhang B.G., and Liu Y. et al., and the group of Lloyd J.R., Morris K. and Boothman C. et al., which produced $62,57,48$, and 44 publications, respectively. It should be noticed that there were couples of research groups that have concentrated on publishing in recent years (2015-2018), and these colored by purple rings in the figure, indicating new researchers and potential development in this field, such as the group of Capodaglio A.G. and Cecconet D., as well as the group of Wang H.Y. and Yang K. The research topics of the groups mentioned above are summarized in Table 2. 

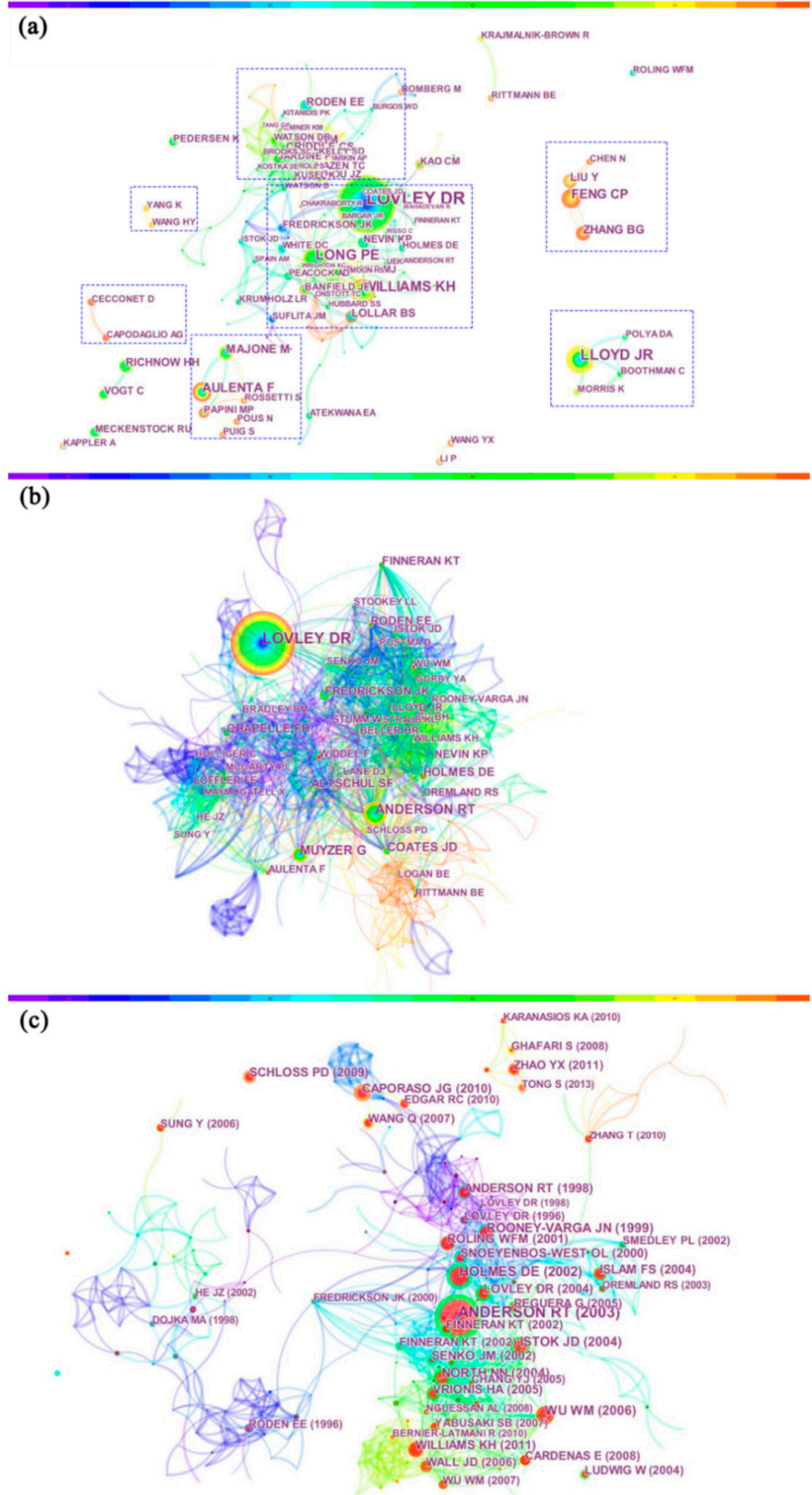

Figure 5. The network map of the productive authors and cited publications of BESs for groundwater remediation during 1999-2018. (a) Shows the authors with five or more publications, and the research groups are highlighted by blue dotted box; (b) shows the authors whose publications have been cited 50 times or more; and (c) shows the publications which have been cited 20 times or more. 
Table 2. Typical researcher groups of BESs for groundwater remediation during 1999-2018.

\begin{tabular}{|c|c|c|}
\hline Group No. & Authors & Research Topics in this Field \\
\hline 1 & $\begin{array}{l}\text { Lovley D.R., Williams K.H. and } \\
\text { Long P.E. et al. }\end{array}$ & $\begin{array}{l}\text { Dissimilatory Fe(III) and } \mathrm{Mn}(\mathrm{IV}) \text { reduction [94]; } \\
\text { Uranium(VI) bioreduction }[80,81,95,96] ; \text { Anaerobic } \\
\text { benzene degradation [97]; }\end{array}$ \\
\hline 2 & $\begin{array}{l}\text { Criddle C.S., Wu W.M. and Hazen } \\
\text { T.C. et al. }\end{array}$ & $\begin{array}{l}\text { Microbial fuel cells [98]; Uranium(VI) bioremediation } \\
\text { [99-102]; Carbon tetrachloride bioremediation [103]; }\end{array}$ \\
\hline 3 & $\begin{array}{l}\text { Aulenta F., Majone M. and Papini } \\
\text { M.P. et al. }\end{array}$ & Microbial dechlorination $[21,45,104-114]$; \\
\hline 4 & $\begin{array}{l}\text { Feng C.P., Zhang B.G., and Liu Y. } \\
\text { et al. }\end{array}$ & $\begin{array}{c}\text { Biofilm electrode reactor denitrification }[115,116] ; \\
\text { Vanadium (V) bioremediation with microbial fuel cell } \\
{[75,76,117] \text {; Nitrate removal with microbial fuel cell }} \\
{[118,119] \text {; Pyridine and methyl orange removal with }} \\
\text { microbial fuel cell }[120,121] ;\end{array}$ \\
\hline 5 & $\begin{array}{l}\text { Lloyd J.R., Morris K. and } \\
\text { Boothman C. et al. }\end{array}$ & $\begin{array}{l}\text { Metal-reducing bacteria [72]; Bioremediation of uranium } \\
{[79,80,122] \text {; Detection and bioremediation of technetium }} \\
\text { [12-125]; }\end{array}$ \\
\hline 6 & Cecconet D. and Capodaglio A.G. & $\begin{array}{c}\text { Groundwater denitrification [47,126,127]; Energy } \\
\text { consumption [49]; Metals and perchlorate removal [25]; } \\
\text { Microbial fuel cell }[49,128,129] ;\end{array}$ \\
\hline 7 & Wang H.Y. and Yang K. & $\begin{array}{l}\text { Autohydrogenotrophic denitrification }[130,131] \text {; } \\
\text { Bioelectrochemical denitrification }[54,132,133]\end{array}$ \\
\hline
\end{tabular}

According to the results mentioned above, the research groups on BESs for groundwater remediation can be divided into two classes according to the research themes: (1) The research originating from microorganisms in groundwater/aquifer sediments that can obtain energy for growth by electron transport [96], as well as further related research including sulfate/dissimilatory Fe(III) reducing bacteria [94,99,134-137]; the bioremediation of radioactive contaminants such as uranium, strontium, and technetium [80,123,125,138]; extracellular electron transfer [139,140]; microbial biocathodes [141,142]; microbial community and geochemical conditions $[113,143]$. The representative researchers are clustered into groups as shown in Table 2 and are numbered 1, 2, 3 and 5. (2) The research originating from the microorganisms that can generate electrical energy during growth [144], as well as further related research focused on the design and application of microbial electric systems/devices for groundwater remediation, including microbial fuel cells $[43,76,128,145,146]$ and microbial electrolysis cells $[48,57]$, and the typical research groups are numbered with 4,6 and 7 in Table 2.

The most cited authors and publications are illustrated by Figure $5 b, c$, and the top $10 \%$ of most cited items in each time slice were used to merge the network. According to the network summary, 557 authors and their publications were analyzed, and the cited frequency of one author ranged from 2 to 566, with an average value of 16. Lovley D.R., Anderson R.T., Muyzer G., Coates J.D., Fredrickson J.K., Chapelle F.H., Holmes D.E., Roden E.E., Finneran K.T. and Altschul S.F. are the top 10 cited authors in this field whose publications have been cited more than 100 times and have accumulated 1962 times as total. There are 29 authors of whose publications cited frequencies are larger than 50 .

Table 3 shows the most cited publications in this field during 1999-2018, most of which were published during 2000-2005 and mainly focused on in-situ bioremediation of uranium-contaminated aquifer or microbial communities in the contaminated-aquifer. For instance, pilot-tests of groundwater $\mathrm{U}(\mathrm{VI})$ reduction was conducted by Anderson et al. [78], Wu et al. [102] and Vrionis et al. [147] in field sites using organic matters (acetate and ethanol) as electron donors to stimulate the growth of metal-reducing microorganisms (Geobacter species), Rooney-Varga et al. [148] found significant increase in Geobacteraceae within the zone of benzene degradation sediments, Reguera et al. [140] found that electrons transfer from the cell surface of Geobacter sulfurreducens to the surface of $\mathrm{Fe}(\mathrm{III})$ oxides while the pili of cell served as biological nanowires, and Lovley et al. [94] systematically summarized the 
environmental significant of $\mathrm{Fe}(\mathrm{III})$-and $\mathrm{Mn}$ (IV)-reducing microorganisms. It should be noticed that the cited frequency in Table 3 is the number that being cited by the publications within the scope of BESs for groundwater remediation (different from the cited number in the citation report of Web Of Science), and the emphasis of the research mentioned above-such as the bacterial community structure during in-situ bioremediation, the geochemical heterogeneity in the bioremediation field site, and the electrons transfer via microbial nanowires during Fe(III) reduction-are sort of the unity of microbiology, biochemistry, and hydrology, and could be considered as the infancy of the research of BESs for groundwater remediation.

Table 3. Summary of the top 10 cited publications of BESs for groundwater remediation during 1999-2018.

\begin{tabular}{|c|c|c|c|c|}
\hline $\begin{array}{c}\text { Cited } \\
\text { Frequency }\end{array}$ & Author & Title & $\begin{array}{l}\text { Published } \\
\text { Year }\end{array}$ & Published Journal \\
\hline 102 & Anderson R.T. et al. & $\begin{array}{l}\text { Stimulating the in situ activity of } \\
\text { geobacter species to remove } \\
\text { uranium from the groundwater of } \\
\text { a uranium-contaminated aquifer. }\end{array}$ & 2003 & $\begin{array}{l}\text { APPL. ENVIRON. } \\
\text { MICROB. }\end{array}$ \\
\hline 61 & Holmes D.E. et al. & $\begin{array}{l}\text { Enrichment of members of the } \\
\text { family geobacteraceae associated } \\
\text { with stimulation of dissimilatory } \\
\text { metal reduction in } \\
\text { uranium-contaminated aquifer } \\
\text { sediments. }\end{array}$ & 2002 & $\begin{array}{l}\text { APPL. ENVIRON. } \\
\text { MICROB. }\end{array}$ \\
\hline 49 & Istok J.D. et al. & $\begin{array}{l}\text { In situ bioreduction of technetium } \\
\text { and uranium in a } \\
\text { nitrate-contaminated aquifer. }\end{array}$ & 2004 & $\begin{array}{l}\text { ENVIRON. SCI. } \\
\text { TECHNOL. }\end{array}$ \\
\hline 45 & $\begin{array}{l}\text { Rooney-Varga J.N. } \\
\text { et al. }\end{array}$ & $\begin{array}{l}\text { Microbial communities associated } \\
\text { with anaerobic benzene } \\
\text { degradation in a } \\
\text { petroleum-contaminated aquifer. }\end{array}$ & 1999 & $\begin{array}{l}\text { APPL. ENVIRON. } \\
\text { MICROB. }\end{array}$ \\
\hline 44 & Wu W.M. et al. & $\begin{array}{l}\text { Pilot-scale in situ bioremedation } \\
\text { of uranium in a highly } \\
\text { contaminated aquifer. } 2 \text {. } \\
\text { reduction of U(VI) and } \\
\text { geochemical control of U(VI) } \\
\text { bioavailability. }\end{array}$ & 2006 & $\begin{array}{l}\text { ENVIRON. SCI. } \\
\text { TECHNOL. }\end{array}$ \\
\hline 43 & North N.N. et al. & $\begin{array}{l}\text { Change in bacterial community } \\
\text { structure during in situ } \\
\text { biostimulation of subsurface } \\
\text { sediment co-contaminated with } \\
\text { uranium and nitrate. }\end{array}$ & 2004 & $\begin{array}{l}\text { APPL. ENVIRON. } \\
\text { MICROB. }\end{array}$ \\
\hline 41 & Vrionis H.A. et al. & $\begin{array}{l}\text { Microbiological and geochemical } \\
\text { heterogeneity in an in situ } \\
\text { uranium bioremediation field site. }\end{array}$ & 2005 & $\begin{array}{l}\text { APPL. ENVIRON. } \\
\text { MICROB. }\end{array}$ \\
\hline 40 & Lovley D.R. et al. & $\begin{array}{l}\text { Dissimilatory } \mathrm{Fe}(\mathrm{III}) \text { and } \mathrm{Mn}(\mathrm{IV}) \\
\text { reduction. }\end{array}$ & 2004 & $\begin{array}{l}\text { ADV. MICROB. } \\
\text { PHYSIOL. }\end{array}$ \\
\hline 40 & Caporaso J.P. et al. & $\begin{array}{l}\text { QIIME allows analysis of } \\
\text { high-throughput community } \\
\text { sequencing data. }\end{array}$ & 2010 & NAT. METHODS \\
\hline 37 & Reguera G. et al. & $\begin{array}{l}\text { Extracellular electron transfer via } \\
\text { microbial nanowires. }\end{array}$ & 2005 & NATURE \\
\hline
\end{tabular}




\subsection{Keywords and Burst Term Detection Analysis}

Keywords, generally representing the research areas and topics, are of great significance to the publications, and keyword analysis is an efficient approach to detect the development and the research frontier of a certain research field [90]. Here, the whole time slice in this study was cut into four pieces (every five years), and the top $10 \%$ cited items of each sub-time slice awee analyzed and merged into the network map by Citespace V. A total of 687 keywords were detected by Citespace V, 74.4\% of which were repetitive among the four time slices. The combination of these repetitive keywords indicates that the main research in this field has been focused on the bioremediation/biodegradation of multiple contaminants, such as organic compounds (BTEX, PAHs, tetrachloroethene, etc.), metallic compounds ( $\mathrm{U}(\mathrm{VI}), \mathrm{Cr}(\mathrm{VI}), \mathrm{V}(\mathrm{V})$, etc.), and non-metallic inorganic compounds (nitrate, sulfate, perchlorate, etc.) in groundwater/aquifer or sediments; the research related to microbial diversity, reducing bacteria, electron acceptor/donors, microbial fuel cell, etc., has been highlighted. As shown in Figure 6, the network map developed with the amount of high cited keywords, and co-occurrence increased over time. The most cited keywords appeared to constantly increase among the four sub-time slices. For instance, the cited frequency of "groundwater" and "bioremediation" were 70, 99, 159, 221 and 28, 59, 74, 77 during 1999-2003, 2004-2008, 2009-2013, and 2014-2018 time slices, respectively, indicating that research in this field has attracted more attention over time. In contrast, the number of the total keywords detected by Citespace $\mathrm{V}$ in each sub-time slice showed a decrease trend over time $(217,195,149$ and 126, respectively), and a possible reason is that the research topics in this field were scattered in the preliminary period, with continually a deepening study the research concentrating and focusing on relatively fewer topics. Moreover, after excluding the repetitive keywords, the changing of the research topics is revealed by the remained keywords among different time slices and which can be generally classified into three catalogs: (1) Reactive materials/contaminants; (2) reactions/processes; and (3) experimental apparatus/microorganisms. The typical non-repetitive keywords are summarized in Table 4 .

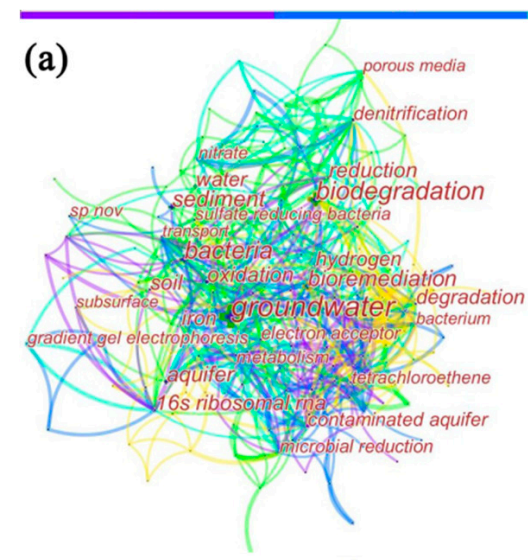

(c)

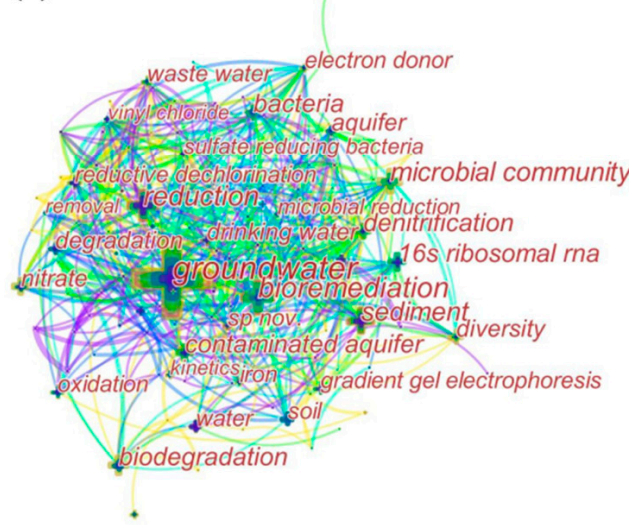

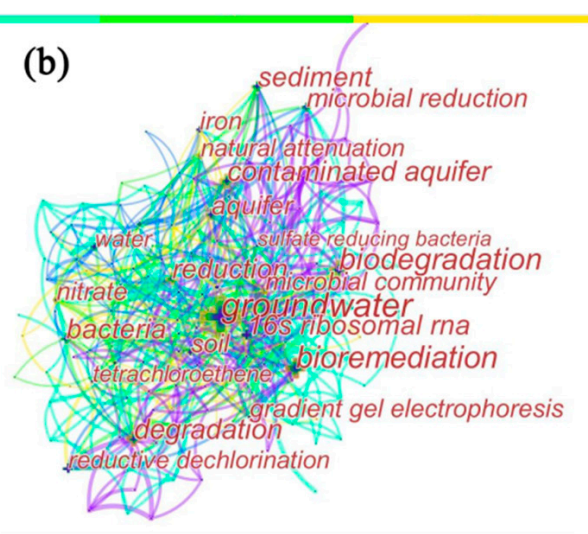

(d)

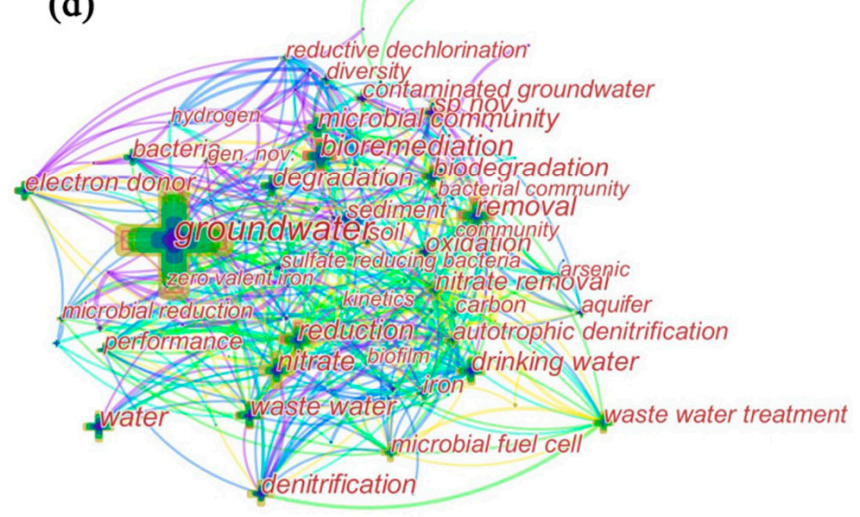

Figure 6. The network map of the keywords of the publications related to BESs for groundwater remediation during 1999-2018. (a) 1999-2004, (b) 2005-2009, (c) 2010-2014, (d) 2015-2018. 
Table 4. Typical non-repetitive keywords of the publications related to BESs for groundwater remediation among different time slices.

\begin{tabular}{|c|c|c|c|}
\hline $\begin{array}{l}\text { Time Slice/Keywords } \\
\text { Catalogs }\end{array}$ & $\begin{array}{c}\text { Reactive } \\
\text { Materials/Contaminants }\end{array}$ & Reactions/Processes & $\begin{array}{c}\text { Experimental } \\
\text { Apparatus/Microorganism }\end{array}$ \\
\hline 1999-2003 & $\begin{array}{c}\text { phenol } \\
\text { monoaromatic } \\
\text { hydrocarbon } \\
\text { petroleum hydrocarbon }\end{array}$ & $\begin{array}{c}\text { electron accepting process } \\
\text { biomineralization } \\
\text { anaerobic benzene oxidation } \\
\text { / }\end{array}$ & $\begin{array}{c}\text { biofilm reactor } \\
\text { biofilter } \\
\text { / }\end{array}$ \\
\hline 2004-2008 & $\begin{array}{c}\text { hydrous ferric oxide } \\
\text { benzylsuccinate synthase }\end{array}$ & $\begin{array}{c}\text { in situ hybridization } \\
\text { dissimilatory sulfite reductase }\end{array}$ & $\begin{array}{l}\text { pseudomonas putida } \\
\text { hollow fiber membrane }\end{array}$ \\
\hline $2009-2013$ & activated carbon & in situ biostimulation & / \\
\hline 2014-2018 & $\begin{array}{c}\text { methane } \\
\text { hydrogen peroxide } \\
\text { perchlorate }\end{array}$ & $\begin{array}{l}\text { electricity generation } \\
\text { fermentation }\end{array}$ & $\begin{array}{l}\text { biofilm electrode reactor } \\
\text { biocathode }\end{array}$ \\
\hline
\end{tabular}

The non-repetitive keywords provide by Table 4 indicate that, besides the main research topics mentioned above, studies that were focused on biodegradation of petroleum hydrocarbon were conducted by researchers during 1999-2003, and some researchers used a biofilm reactor/biofilter for groundwater remediation experiments. For instance, the laboratory microcosm experiments performed by Harrison et al. [149] indicated that natural attenuation of diluted phenol contaminated groundwater was feasible in both anaerobic and aerobic conditions, and Gómez et al. [150] used a submerged biological filter to purify nitrate-contaminated groundwater. During 2004-2008, studies focused on groundwater toluene biodegradation were conducted using the benzylsuccinate synthase gene as specific catabolic markers $[143,151]$, biological sulfate reduction column experiments were conducted with dissimilatory sulfite reductase gene as biomarker for the sulfate-reducing bacteria [152], and an experiment of laboratory-scale columns with hollow fiber membranes was performed to investigate a bioremediation technology for perchloroethylene-contaminated aquifers [153]. During 2009-2013, Foo and Hameed [154] summarized the studies of the activated carbon adsorption process for pesticide detoxification and mentioned that the combined electrochemical reactor and adsorber was conducted by former researchers for groundwater remediation. For instance, Feleke and Sakakibara [155] performed an experimental apparatus of an electrochemical reactor coupled with an activated carbon adsorber for the removal of nitrate and an inhibitory pesticide in groundwater. Additionally, an experiment of active carbon reactors for nitrate and arsenic bioremediation was conducted by Upadhyaya et al. [74]. During 2014-2018, a notable change revealed that the keywords related to "electrical" appeared at an intensively increasing tendency, a fusion of multiple subjects such as microbiology, electrochemistry, and hydrology could be determined by the publications, and the research that focused on BESs (such as microbial fuel cell and microbial electrolysis cell) for groundwater nitrate/metallic compounds remediation developed rapidly in this time slice. For instance, experiments of groundwater vanadium $(\mathrm{V})$ remediation were performed using a bioelectrical reactor with electricity generated from a microbial fuel cell, and further experiments were designed to investigate the effects of various organic carbon sources on simultaneous vanadium (V) bioreduction [76,117]. An experiment of microbial electrolysis cell for groundwater autotrophic denitrification was conducted by assessing the conditions of nitrate load, hydraulic retention time and process configuration, and the system proved able to almost completely remove nitrate in all the conditions tested [57]. A study of a denitrifying biocathode installed into the simulated aquifer showed that this system was feasible for the nitrate removal of the saturated aquifer, and the specific nitrate reduction rate was inversely proportional to the sand/medium ratios of the aquifer [156].

As discussed above, keywords analysis is an effective method to determine the overall structure and research topics in a specific research field. However, a high repetition of the general keywords would probably result in the neglecting of the research hotspots. Citespace uses Kleinberg's burst-detection algorithm to identify emergent research-front concepts [91], and similar concepts/terms are further coalesced into clusters that represent the related research field. The size of a cluster is proportional 
to the amount of the terms included, and the clusters are numbered from the largest to the smallest, with an identify number (ID, hereinafter) starting from 0 . As shown in Figure 7, the burst terms in this field were classified into dozens of clusters, and clusters 0-9 made up the majority of the overall publications and citations in this field. Cluster 5-7 showed extensive citations at the beginning of the time slice (the purple and dark blue lines in Figure 7), with cluster ID natural attenuation, other priority radionuclide, and novel Fe, respectively, indicating the research related to the in-situ remediation of radioactive contaminants with dissimilatory Fe(III) reduction bacteria was the early research emphasis in this field. Then, the research hotspots transferred to reductive dechlorination and sulfate reducing bacteria, with clusters ID 2 and 1. During 2004-2010, research focused on microbial fuel cells developed rapidly (Cluster ID 4 in Figure 7), as revealed by the dense green lines representing the citation. Furthermore, the research focused on BESs has shown an intensive increase since 2010, as revealed by the largest cluster with ID 0 , indicating more attention has been attracted in recent years.

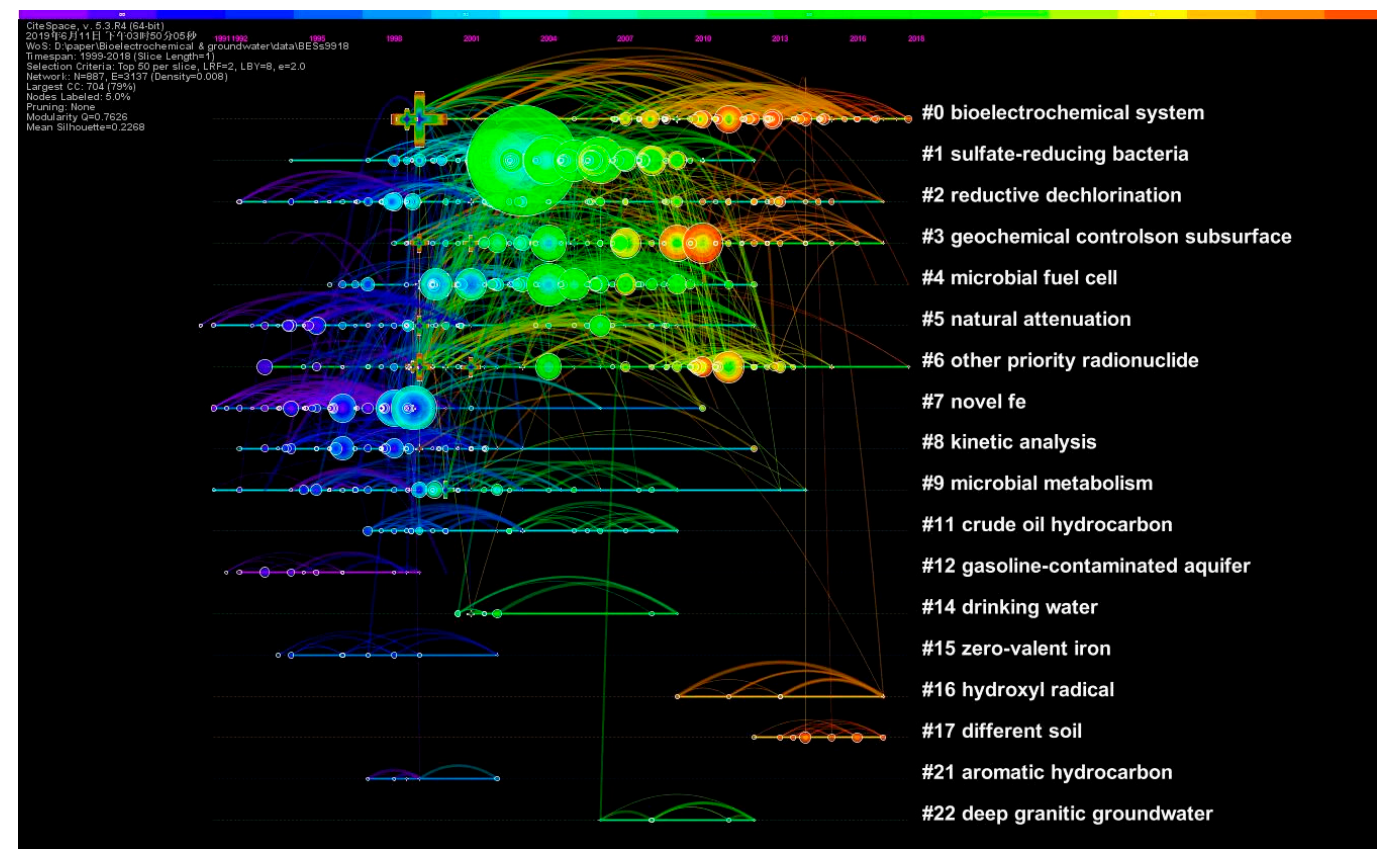

Figure 7. The network timeline map of the burst terms cluster of the publications related to BESs for groundwater remediation during 1999-2018. Each node in the figure represents a high cited paper that belongs to the cluster and the colorful lines represent the time of being cited.

\section{Discussion and Perspectives}

With the development of research concepts, methods, technology and reality needs, the research topics of BESs for groundwater remediation have changed in the last two decades. This was partly revealed by the keywords and burst terms analysis mentioned above, as well as the development trend of which can further be considered to follow two routes roughly.

The first one was mainly focused on the research of microbial reduction mechanisms, beginning with the research of the microbial reduction of certain pollutants such as uranium and benzene [96,97], with a particular focus on dissimilatory Fe(III)-reducing microorganisms that can obtain energy for growth by electron transport to U(VI) [96]. This finding opened the door to a new bio-remediation method. Subsequently, the research of extracellular electron transfer by the microorganisms developed continually, from the outer-membrane cytochromes to the pili that served as biological nanowires [140], and this study was further combined with the research of electrical self-potential [65]. Thus, studies focused on "biogeobattery" raised in number [66,67], and the latest studies have conducted field investigations on the bioremediation of uranium-contaminated groundwater and have focused on microbial diversity [80,81]. In brief, the studies following this route were mainly interdisciplinary 
(crossing of microbiology, electrochemistry, genetics, etc.) and had an emphasis on the microbial electrochemical/biochemical reactions during the groundwater bioremediation process, rather than the design and invention of bioelectrochemical systems/devices.

The second route can be considered to have begun with the concept of the microbial fuel cell (MFC, that microorganisms can generate electricity with hydrocarbons as carbon source for growth [144]). Thus, this technology is particularly suitable for the treatment of wastewater with a relatively abundant amount of available carbon, such as the domestic effluent [157-159], and bioelectrochemical systems/devices were initially designed for this purpose. Along with the deepening of research, the research topics that originated from the MFC developed and concentrated on multiple subjects, e.g., the power production [60], anode performance [98], operating conditions [160], the MFC process model [129], microbial electrolysis [61], and microbial desalination [23,62,86]. The treated pollutants changed from hydrocarbons in the early study period to various contaminants such as ammonia [161], nitrate [43,145], sulfate [162], perchlorate [59] and vanadium [76,117]. Recent studies have further optimized BESs for better performances by using different electrode such as stainless steel [53], carbon paper [163], and graphite [84,128], and these BESs have been improved from single chamber to dual chamber with cationic exchange membrane $[57,164]$.

Previous studies have demonstrated that BESs are particularly suitable for the removal of various contaminants in groundwater, owing to their advantages on efficiency, flexibility, and cost-saving; however, most of the BESs for groundwater remediation studies, at the present stage, were conducted as lab-experiment and pilot tests. Additionally, in-situ remediation projects have been scarce, and there are several challenges that should be considered for the further study and application of BESs for groundwater remediation.

The complexity of hydrogeological conditions in reality is a dominating factor that influences remedial performance. Natural groundwater is normally neutral with little or no organic matter [57], while the experiments of BESs have shown a relatively fluctuant $\mathrm{pH}$ around the electrodes, with the $\mathrm{pH}$ of the catholyte maintaining a level between 9 and 9.5 [146], occasionally even raising to 11.7 at the cathode zone [115]. Thus, $\mathrm{pH}$ adjustment is necessary to sustain and enhance the biological activity in BESs [165]. However, this strategy is difficult to achieve in real conditions, owing to the strong buffering capacity of groundwater [166]. Besides, the supplements of the substrates (carbon source) like wastewater should be cautioned to avoid introducing other contaminants into groundwater [167]. Moreover, BESs experiments have indicated that the reduction rate of pollutants (such as nitrate) is highly related to aquifer composition $[156,168]$. Thus, aquifer heterogeneity would significantly affect the BESs operation for real groundwater remediation, and further study should be conducted to allow the presence of optimal conditions for bioelecrochemical reactions (such as $\mathrm{pH}$ and carbon source control) and to invent BESs for specific hydrogeological conditions (considering the stratum structure, water table, aquifer media, etc.).

The screening of groundwater remedial technology is complicated, owing to its multiple criteria involving technique, economy and policy [26]. Being an in-situ technology, BESs have unique advantages on cost-saving rather than the energy-intensive ex-situ alternatives such as pump and treat [51]. However, the lack of pilot scale studies and in-situ remediation projects makes it difficult to accurately evaluate the actual cost of conducting a real BESs remedial project; increasing the distance between the anode and cathode (as in the remedial field) would cause a decrease of the MFC cell potential and reduction efficiency [88], which would result in a direct impact on the cost. Besides, mots of BESs studies at present have been conducted from days to months $[47,56,59,132]$, while the long term operational stability of BESs for groundwater remediation is still questionable. Thereby, scaling up the BESs to an applicable size and conducting long term BESs remedial studies should be implemented in future.

The combined pollution with contaminants of different chemical natures in groundwater is an emerging issue $[42,169]$. Thus, BESs for groundwater combined pollution remediation are highly expected. However, the microbial reduction experimental study conducted by Xie et al. [170] indicated 
that the presence of nitrate slowed the reduction of perchlorate at the inoculated cathode, increasing concentration of nitrate would resulted in a noticeable inhibitory effect on perchlorate reduction; similar results were found by Feleke and Sakakibara [155], such that increasing pesticide loading would inhibit the reduction of nitrate in a bio-electrochemical reactor experiment. Considering variable groundwater pollution issues related to industrial (heavy metals [171,172], petrol hydrocarbons [173,174], etc.), agricultural (pesticide $[154,175,176]$, nitrate $[57,139,156]$, etc.) and human activities (nitrogen [3,146,177], antibiotics [31], etc.), inhibition effects due to the combination of different pollutants should be taken into consideration for further study. Moreover, there are factors directly affecting the performance of BESs such as microbial diversity and competition as well as energy consumption and recovery that researchers have to face and which demand an increase of unremitting efforts in the future.

\section{Conclusions}

The research focused on BESs for groundwater remediation developed rapidly during 1999-2018, with yearly publication continuously increasing from 34 to 151 . USA predominated the research in this field at the early stage, but its amount of publications increased slowly in recent years, in contrast the annual growth rates of the publications of China, Germany and Italy, which were $52 \%, 32 \%$ and $31 \%$ in the last decade, respectively. The national research funds/councils have been the dominant funding sources of the research in this field. The top 10 journals including Environmental Science $\mathcal{E}$ Technology, Applied and Environmental Microbiology, and Water Research have accounted for $36 \%$ of the total publications and $47 \%$ of the total citations. The main research in this field have been focused on the bioremediation/biodegradation of multiple contaminants such as organic compounds (BTEX, PAHs, tetrachloroethene, etc.), metallic compounds $(\mathrm{U}(\mathrm{VI}), \mathrm{Cr}(\mathrm{VI}), \mathrm{V}(\mathrm{V})$, etc.) and non-metallic inorganic compounds (nitrate, sulfate, perchlorate, etc.) in groundwater/aquifer or sediments, and the research related to the microbial diversity, reducing bacteria, electron acceptor/donor and microbial fuel cell, etc., have been highlighted.

Author Contributions: W.L. and X.C. designed this research; L.X. and Z.L. collected the data; W.L. and Z.L. analyzed the data and wrote the draft. W.L. and X.X. revised the manuscript. All authors read and approved the final manuscript.

Funding: This research was funded by the National Natural Science Foundation of China (NSFC) (Grant No. 41702276), the Major Science and Technology Program for Water Pollution Control and Treatment of China (Grant No. 2015ZX07206-006), and Shenzhen basic research plan (JCYJ20160429191638556).

Acknowledgments: The authors are grateful to the editors and the anonymous reviewers for their constructive comments and suggested revisions.

Conflicts of Interest: The authors declare no conflict of interest.

\section{References}

1. Stephen, F.; Daniel, P.L. Non-Renewable Groundwater Resouecrs; United Nations Educational, Scientific and Cultural Organization: Paris, France, 2006; pp. 13-25.

2. Yao, Y.; Zheng, C.; Andrews, C.; He, X.; Zhang, A.; Liu, J. Integration of groundwater into China's south-north water transfer strategy. Sci. Total. Environ. 2019, 658, 550-557. [CrossRef] [PubMed]

3. Sun, J.J.; Chen, L.; Rene, E.R.; Hu, Q.; Ma, W.F.; Shen, Z.Y. Biological nitrogen removal using soil columns for the reuse of reclaimed water: Performance and microbial community analysis. J. Environ. Manag. 2018, 217, 100-109. [CrossRef] [PubMed]

4. Li, W.; Wang, M.-y.; Liu, L.-y.; Wang, H.-f.; Yu, S. Groundwater heavy metal levels and associated human health risk in the North China Plain. Arab. J. Geosci. 2015, 8, 10389-10398. [CrossRef]

5. Gejl, R.N.; Rygaard, M.; Henriksen, H.J.; Rasmussen, J.; Bjerg, P.L. Understanding the impacts of groundwater abstraction through long-term trends in water quality. Water Res. 2019, 241-251. [CrossRef] [PubMed]

6. Mudiam, M.K.; Pathak, S.P.; Gopal, K.; Murthy, R.C. Studies on urban drinking water quality in a tropical zone. Environ. Monit. Assess. 2012, 184, 461-469. [CrossRef] [PubMed] 
7. Sevda, S.; Sreekishnan, T.R.; Pous, N.; Puig, S.; Pant, D. Bioelectroremediation of perchlorate and nitrate contaminated water: A review. Bioresour. Technol. 2018, 255, 331-339. [CrossRef] [PubMed]

8. Wakode, H.B.; Baier, K.; Jha, R.; Azzam, R. Impact of urbanization on groundwater recharge and urban water balance for the city of Hyderabad, India. Int. Soil Water Conserv. Res. 2018, 6, 51-62. [CrossRef]

9. Shrestha, A.; Luo, W. Assessment of Groundwater Nitrate Pollution Potential in Central Valley Aquifer Using Geodetector-Based Frequency Ratio (GFR) and Optimized-DRASTIC Methods. Int. J. Geo-Inf. 2018, 7, 211. [CrossRef]

10. Bouzourra, H.; Bouhlila, R.; Elango, L.; Slama, F.; Ouslati, N. Characterization of mechanisms and processes of groundwater salinization in irrigated coastal area using statistics, GIS, and hydrogeochemical investigations. Environ. Sci. Pollut. Res. Int. 2015, 22, 2643-2660. [CrossRef]

11. Liu, F.; Song, X.; Yang, L.; Han, D.; Zhang, Y.; Ma, Y.; Bu, H. The role of anthropogenic and natural factors in shaping the geochemical evolution of groundwater in the Subei Lake basin, Ordos energy base, Northwestern China. Sci. Total. Environ. 2015, 538, 327-340. [CrossRef]

12. Matiatos, I. Nitrate source identification in groundwater of multiple land-use areas by combining isotopes and multivariate statistical analysis: A case study of Asopos basin (Central Greece). Sci. Total. Environ. 2016, 541, 802-814. [CrossRef] [PubMed]

13. Cuoco, E.; Darrah, T.H.; Buono, G.; Verrengia, G.; De Francesco, S.; Eymold, W.K.; Tedesco, D. Inorganic contaminants from diffuse pollution in shallow groundwater of the Campanian Plain (Southern Italy). Implications for geochemical survey. Environ. Monit. Assess. 2015, 187, 46. [CrossRef] [PubMed]

14. Krishna, A.K.; Mohan, K.R. Risk assessment of heavy metals and their source distribution in waters of a contaminated industrial site. Environ. Sci. Pollut. Res. Int. 2014, 21, 3653-3669. [CrossRef] [PubMed]

15. Tang, R.; Wu, D.; Chen, W.; Feng, C.; Wei, C. Biocathode denitrification of coke wastewater effluent from an industrial aeration tank: Effect of long-term adaptation. Biochem. Eng. J. 2017, 125, 151-160. [CrossRef]

16. Belhaj, E.; Lafhaj, Z.; Zakaria, K.; Depelsenaire, G. Formulation of a Permeable Reactive Mixture for Groundwater Remediation Based on an Industrial Co-product: Permeability and Copper Retention Study. Waste and Biomass Valorization 2015, 6, 263-272. [CrossRef]

17. Pradhan, J.K.; Kumar, S. Informal e-waste recycling: environmental risk assessment of heavy metal contamination in Mandoli industrial area, Delhi, India. Environ. Sci. Pollut. Res. Int. 2014, 21, 7913-7928. [CrossRef] [PubMed]

18. Krishna, A.K.; Satyanarayanan, M.; Govil, P.K. Assessment of heavy metal pollution in water using multivariate statistical techniques in an industrial area: a case study from Patancheru, Medak District, Andhra Pradesh, India. J. Hazard. Mater. 2009, 167, 366-373. [CrossRef]

19. Nizami, A.S.; Rehan, M.; Waqas, M.; Naqvi, M.; Ouda, O.K.M.; Shahzad, K.; Miandad, R.; Khan, M.Z.; Syamsiro, M.; Ismail, I.M.I.; et al. Waste biorefineries: Enabling circular economies in developing countries. Bioresour. Technol. 2017, 241, 1101-1117. [CrossRef]

20. Wang, Y.; Pleasant, S.; Jain, P.; Powell, J.; Townsend, T. Calcium carbonate-based permeable reactive barriers for iron and manganese groundwater remediation at landfills. Waste Manag. 2016, 53, 128-135. [CrossRef]

21. Aulenta, F.; Di Maio, V.; Ferri, T.; Majone, M. The humic acid analogue antraquinone-2,6-disulfonate (AQDS) serves as an electron shuttle in the electricity-driven microbial dechlorination of trichloroethene to cis-dichloroethene. Bioresour. Technol. 2010, 101, 9728-9733. [CrossRef]

22. Compernolle, T.; Van Passel, S.; Huisman, K.; Kort, P. The option to abandon: stimulating innovative groundwater remediation technologies characterized by technological uncertainty. Sci. Total. Environ. 2014, 496, 63-74. [CrossRef] [PubMed]

23. Huang, J.; Ewusi-Mensah, D.; Norgbey, E. Microbial desalination cells technology: a review of the factors affecting the process, performance and efficiency. Desalin. Water Treat. 2017, 87, 140-159. [CrossRef]

24. Liu, Y.; Mou, H.; Chen, L.; Mirza, Z.A.; Liu, L. Cr(VI)-contaminated groundwater remediation with simulated permeable reactive barrier (PRB) filled with natural pyrite as reactive material: Environmental factors and effectiveness. J. Hazard. Mater. 2015, 298, 83-90. [CrossRef] [PubMed]

25. Cecconet, D.; Callegari, A.; Capodaglio, A.G. Bioelectrochemical Systems for Removal of Selected Metals and Perchlorate from Groundwater: A Review. Energies 2018, 11, 2643. [CrossRef]

26. Li, W.; Zhang, M.; Wang, M.; Han, Z.; Liu, J.; Chen, Z.; Liu, B.; Yan, Y.; Liu, Z. Screening of groundwater remedial alternatives for brownfield sites: a comprehensive method integrated MCDA with numerical simulation. Environ. Sci. Pollut. Res. Int. 2018, 25, 15844-15861. [CrossRef] [PubMed] 
27. Sadeghfam, S.; Hassanzadeh, Y.; Khatibi, R.; Nadiri, A.A.; Moazamnia, M. Groundwater Remediation through Pump-Treat-Inject Technology Using Optimum Control by Artificial Intelligence (OCAI). Water Resour. Manag. 2019, 33, 1123-1145. [CrossRef]

28. Guo, Z.; Brusseau, M.L.; Fogg, G.E. Determining the long-term operational performance of pump and treat and the possibility of closure for a large TCE plume. J. Hazard. Mater. 2019, 365, 796-803. [CrossRef]

29. Yudao, C.; Yaping, C.; Yaping, J.; Yani, Y.; Zhiteng, L.; Qiling, T.; Zisen, S. Pump-and-treat method to remove nitrate from groundwater with liquor as the carbon source. Environ. Earth Sci. 2017, 76. [CrossRef]

30. Boal, A.K.; Rhodes, C.; Garcia, S. Pump-and-Treat Groundwater Remediation Using Chlorine/Ultraviolet Advanced Oxidation Processes. Groundw. Monit. Remediat. 2015, 35, 93-100. [CrossRef]

31. Zhao, P.; Yu, F.; Wang, R.; Ma, Y.; Wu, Y. Sodium alginate/graphene oxide hydrogel beads as permeable reactive barrier material for the remediation of ciprofloxacin-contaminated groundwater. Chemosphere 2018, 200, 612-620. [CrossRef]

32. McCobb, T.D.; Briggs, M.A.; LeBlanc, D.R.; Day-Lewis, F.D.; Johnson, C.D. Evaluating long-term patterns of decreasing groundwater discharge through a lake-bottom permeable reactive barrier. J. Environ. Manag. 2018, 220, 233-245. [CrossRef] [PubMed]

33. Ma, J.; Stevens, G.W.; Mumford, K.A. The effect of temperature on hydrocarbon adsorption by diphenyldichlorosilane coated zeolite and its application in permeable reactive barriers in cold regions. Cold Reg. Sci. Technol. 2018, 145, 169-176. [CrossRef]

34. Kornilovych, B.; Wireman, M.; Ubaldini, S.; Guglietta, D.; Koshik, Y.; Caruso, B.; Kovalchuk, I. Uranium Removal from Groundwater by Permeable Reactive Barrier with Zero-Valent Iron and Organic Carbon Mixtures: Laboratory and Field Studies. Metals 2018, 8, 408. [CrossRef]

35. Gholami, F.; Shavandi, M.; Dastgheib, S.M.M.; Amoozegar, M.A. Naphthalene remediation form groundwater by calcium peroxide (CaO2) nanoparticles in permeable reactive barrier (PRB). Chemosphere 2018, 212, 105-113. [CrossRef] [PubMed]

36. Carroll, K.C.; Oostrom, M.; Truex, M.J.; Rohay, V.J.; Brusseau, M.L. Assessing performance and closure for soil vapor extraction: integrating vapor discharge and impact to groundwater quality. J. Contam. Hydrol. 2012, 128, 71-82. [CrossRef] [PubMed]

37. Lee, J.H.; Woo, H.J.; Jeong, K.S. Removal of non-aqueous phase liquids (NAPLs) from TPH-saturated sandy aquifer sediments using in situ air sparging combined with soil vapor extraction. J. Environ. Sci. Health A Tox Hazard Subst. Environ. Eng. 2018, 53, 1253-1266. [CrossRef]

38. Behar, H.R.; Snyder, E.E.; Marczak, S.; Salazar, L.J.; Rappe, B.; Fordham, G.F.; Chu, S.P.; Strobridge, D.M.; Birdsell, K.H.; Miller, T.A.; et al. An Investigation of Plume Response to Soil Vapor Extraction and Hypothetical Drum Failure. Vadose Zone J. 2019, 18. [CrossRef]

39. Kawabe, Y.; Komai, T. A Case Study of Natural Attenuation of Chlorinated Solvents Under Unstable Groundwater Conditions in Takahata, Japan. Bull. Environ. Contam. Toxicol. 2019, 102, 280-286. [CrossRef]

40. Caschetto, M.; Robertson, W.; Petitta, M.; Aravena, R. Partial nitrification enhances natural attenuation of nitrogen in a septic system plume. Sci. Total. Environ. 2018, 625, 801-808. [CrossRef]

41. Rodriguez-Fernandez, D.; Torrento, C.; Palau, J.; Marchesi, M.; Soler, A.; Hunkeler, D.; Domenech, C.; Rosell, M. Unravelling long-term source removal effects and chlorinated methanes natural attenuation processes by $\mathrm{C}$ and $\mathrm{Cl}$ stable isotopic patterns at a complex field site. Sci. Total. Environ. 2018, 645, 286-296. [CrossRef]

42. Pous, N.; Dolors Balaguer, M.; Colprim, J.; Puig, S. Opportunities for groundwater microbial electro-remediation. Microb. Biotechnol. 2018, 11, 119-135. [CrossRef] [PubMed]

43. Pous, N.; Puig, S.; Coma, M.; Balaguer, M.D.; Colprim, J. Bioremediation of nitrate-polluted groundwater in a microbial fuel cell. J. Chem. Technol. Biotechnol. 2013, 88, 1690-1696. [CrossRef]

44. Hashim, M.A.; Mukhopadhyay, S.; Sahu, J.N.; Sengupta, B. Remediation technologies for heavy metal contaminated groundwater. J Environ. Manag. 2011, 92, 2355-2388. [CrossRef] [PubMed]

45. Lai, A.; Aulenta, F.; Mingazzini, M.; Palumbo, M.T.; Papini, M.P.; Verdini, R.; Majone, M. Bioelectrochemical approach for reductive and oxidative dechlorination of chlorinated aliphatic hydrocarbons (CAHs). Chemosphere 2017, 169, 351-360. [CrossRef] [PubMed]

46. Su, S.G.; Cheng, H.Y.; Zhu, T.T.; Wang, H.C.; Wang, A.J. A novel bioelectrochemical method for real-time nitrate monitoring. Bioelectrochemistry 2019, 125, 33-37. [CrossRef] 
47. Callegari, A.; Bolognesi, S.; Cecconet, D. Operation of a 2-Stage Bioelectrochemical System for Groundwater Denitrification. Water 2019, 11, 959. [CrossRef]

48. Espinoza Tofalos, A.; Daghio, M.; Gonzalez, M.; Papacchini, M.; Franzetti, A.; Seeger, M. Toluene degradation by Cupriavidus metallidurans $\mathrm{CH} 34$ in nitrate-reducing conditions and in Bioelectrochemical Systems. FEMS Microbiol. Lett. 2018, 365. [CrossRef]

49. Cecconet, D.; Zou, S.; Capodaglio, A.G.; He, Z. Evaluation of energy consumption of treating nitrate-contaminated groundwater by bioelectrochemical systems. Sci. Total Environ. 2018, 636, 881-890. [CrossRef]

50. Hen, D.; Yang, K.; Wei, L.; Wang, H.Y. Microbial community and metabolism activity in a bioelectrochemical denitrification system under long-term presence of p-nitrophenol. Bioresour. Technol. 2016, 218, 189-195.

51. Tong, Y.; He, Z. Current-driven nitrate migration out of groundwater by using a bioelectrochemical system. Rsc Advances 2014, 4, 10290-10294. [CrossRef]

52. Wan, D.J.; Liu, H.J.; Qu, J.H.; Lei, P.J.; Mao, S.H.; Hou, Y.N. Using the combined bioelectrochemical and sulfur autotrophic denitrification system for groundwater denitrification. Bioresour. Technol. 2009, 100, 142-148. [CrossRef] [PubMed]

53. Cast, K.L.; Flora, J.R.V. An evaluation of two cathode materials and the impact of copper on bioelectrochemical denitrification. Water Res. 1998, 32, 63-70. [CrossRef]

54. Chen, D.; Wang, X.; Yang, K.; Wang, H. Response of a three dimensional bioelectrochemical denitrification system to the long-term presence of graphene oxide. Bioresour. Technol. 2016, 214, 24-29. [CrossRef] [PubMed]

55. Pous, N.; Puig, S.; Balaguer, M.D.; Colprim, J. Cathode potential and anode electron donor evaluation for a suitable treatment of nitrate-contaminated groundwater in bioelectrochemical systems. Chem. Eng. J. 2015, 263, 151-159. [CrossRef]

56. Van Khanh, N.; Hong, S.; Park, Y.; Jo, K.; Lee, T. Autotrophic denitrification performance and bacterial community at biocathodes of bioelectrochemical systems with either abiotic or biotic anodes. J. Biosci. Bioeng. 2015, 119, 180-187. [CrossRef]

57. Cecconet, D.; Devecseri, M.; Callegari, A.; Capodaglio, A.G. Effects of process operating conditions on the autotrophic denitrification of nitrate-contaminated groundwater using bioelectrochemical systems. Sci. Total Environ. 2018, 613, 663-671. [CrossRef] [PubMed]

58. Adelaja, O.; Keshavarz, T.; Kyazze, G. Treatment of phenanthrene and benzene using microbial fuel cells operated continuously for possible in situ and ex situ applications. Int. Biodeterior. Biodegrad. 2017, 116, 91-103. [CrossRef]

59. Butler, C.S.; Clauwaert, P.; Green, S.J.; Verstraete, W.; Nerenberg, R. Bioelectrochemical Perchlorate Reduction in a Microbial Fuel Cell. Environ. Sc. Technol. 2010, 44, 4685-4691. [CrossRef]

60. Clauwaert, P.; Rabaey, K.; Aelterman, P.; De Schamphe, L. Biological Denitrification in Microbial Fuel Cells. Environ. Sci. Technol. 2007, 41, 3354-3360. [CrossRef]

61. Hennebel, T.; Benner, J.; Clauwaert, P.; Vanhaecke, L.; Aelterman, P.; Callebaut, R.; Boon, N.; Verstraete, W. Dehalogenation of environmental pollutants in microbial electrolysis cells with biogenic palladium nanoparticles. Biotechnol. Lett. 2011, 33, 89-95. [CrossRef]

62. Chen, X.; Xia, X.; Liang, P.; Cao, X.; Sun, H.; Huang, X. Stacked microbial desalination cells to enhance water desalination efficiency. Environ. Sci. Technol. 2011, 45, 2465-2470. [CrossRef] [PubMed]

63. Kim, Y.; Logan, B.E. Microbial desalination cells for energy production and desalination. Desalination 2013, 308, 122-130. [CrossRef]

64. Mehanna, M.; Saito, T.; Yan, J.; Hickner, M.; Cao, X.; Huang, X.; Logan, B.E. Using microbial desalination cells to reduce water salinity prior to reverse osmosis. Energy Environ. Sci. 2010, 3. [CrossRef]

65. Hubbard, C.G.; West, L.J.; Morris, K.; Kulessa, B.; Brookshaw, D.; Lloyd, J.R.; Shaw, S. In search of experimental evidence for the biogeobattery. J. Geophys. Res. 2011, 116. [CrossRef]

66. Revil, A.; Mendonça, C.A.; Atekwana, E.A.; Kulessa, B.; Hubbard, S.S.; Bohlen, K.J. Understanding biogeobatteries: Where geophysics meets microbiology. J. Geophys. Res. 2010, 115. [CrossRef]

67. Risgaard-Petersen, N.; Damgaard, L.R.; Revil, A.; Nielsen, L.P. Mapping electron sources and sinks in a marine biogeobattery. J. Geophys. Res. Biogeosci. 2014, 119, 1475-1486. [CrossRef]

68. Chen, D.; Dai, T.; Wang, H.; Yang, K. Nitrate removal by a combined bioelectrochemical and sulfur autotrophic denitrification (CBSAD) system at low temperatures. Desalin. Water Treat. 2016, 57, 19411-19417. [CrossRef] 
69. Hoseinzadeh, E.; Rezaee, A.; Farzadkia, M. Enhanced biological nitrate removal by alternating electric current bioelectrical reactor: Selectivity and mechanism. J. Mol. Liq. 2017, 246, 93-102. [CrossRef]

70. Krauter, P.; Daily, B., Jr.; Dibley, V.; Pinkart, H.; Legler, T. Perchlorate and nitrate remediation efficiency and microbial diversity in a containerized wetland bioreactor. Int. J. Phytoremed. 2005, 7, 113-128. [CrossRef]

71. Wang, Z.; Gao, M.; Zhang, Y.; She, Z.; Ren, Y.; Wang, Z.; Zhao, C. Perchlorate reduction by hydrogen autotrophic bacteria in a bioelectrochemical reactor. J. Environ. Manag. 2014, 142, 10-16. [CrossRef]

72. Islam, F.; Gault, A.; Boothman, C.; Lloyd, J.R. Role of metal-reducing bacteria in arsenic release from Bengal deltas. Nature 2004, 430, 68-71. [CrossRef] [PubMed]

73. Lloyd, J.R.; Oremland, R.S. Microbial Transformations of Arsenic in the Environment- From Soda Lakes to Aquifers. Elements 2006, 2, 85-90. [CrossRef]

74. Upadhyaya, G.; Jackson, J.; Clancy, T.M.; Hyun, S.P.; Brown, J.; Hayes, K.F.; Raskin, L. Simultaneous removal of nitrate and arsenic from drinking water sources utilizing a fixed-bed bioreactor system. Water Res. 2010, 44, 4958-4969. [CrossRef] [PubMed]

75. Zhang, B.; Feng, C.; Ni, J.; Zhang, J.; Huang, W. Simultaneous reduction of vanadium (V) and chromium (VI) with enhanced energy recovery based on microbial fuel cell technology. J. Power Sources 2012, 204, 34-39. [CrossRef]

76. Hao, L.; Zhang, B.; Tian, C.; Liu, Y.; Shi, C.; Cheng, M.; Feng, C. Enhanced microbial reduction of vanadium (V) in groundwater with bioelectricity from microbial fuel cells. J. Power Sources 2015, 287, 43-49. [CrossRef]

77. Zhang, B.; Hao, L.; Tian, C.; Yuan, S.; Feng, C.; Ni, J.; Borthwick, A.G. Microbial reduction and precipitation of vanadium (V) in groundwater by immobilized mixed anaerobic culture. Bioresour. Technol. 2015, 192, 410-417. [CrossRef]

78. Anderson, R.T.; Vrionis, H.A.; Ortiz-Bernad, I.; Resch, C.T.; Long, P.E.; Dayvault, R.; Karp, K.; Marutzky, S.; Metzler, D.R.; Peacock, A.; et al. Stimulating the in situ activity of Geobacter species to remove uranium from the groundwater of a uranium-contaminated aquifer. Appl. Environ. Microbiol. 2003, 69, 5884-5891. [CrossRef]

79. Newsome, L.; Morris, K.; Lloyd, J.R. The biogeochemistry and bioremediation of uranium and other priority radionuclides. Chem. Geol. 2014, 363, 164-184. [CrossRef]

80. Williams, K.H.; Bargar, J.R.; Lloyd, J.R.; Lovley, D.R. Bioremediation of uranium-contaminated groundwater: a systems approach to subsurface biogeochemistry. Curr. Opin. Biotechnol. 2013, 24, 489-497. [CrossRef]

81. Williams, K.H.; Long, P.E.; Davis, J.A.; Wilkins, M.J.; N'Guessan, A.L.; Steefel, C.I.; Yang, L.; Newcomer, D.; Spane, F.A.; Kerkhof, L.J.; et al. Acetate Availability and its Influence on Sustainable Bioremediation of Uranium-Contaminated Groundwater. Geomicrobiol. J. 2011, 28, 519-539. [CrossRef]

82. Fan, C.; Gao, Y.; Zhang, Y.; Dong, W.; Lai, M. Remediation of lead and cadmium from simulated groundwater in loess region in northwestern China using permeable reactive barrier filled with environmentally friendly mixed adsorbents. Environ. Sci. Pollut. Res. Int. 2018, 25, 1486-1496. [CrossRef] [PubMed]

83. Foght, J. Anaerobic biodegradation of aromatic hydrocarbons: pathways and prospects. J. Mol. Microbiol. Biotechnol. 2008, 15, 93-120. [CrossRef] [PubMed]

84. Zhang, T.; Gannon, S.M.; Nevin, K.P.; Franks, A.E.; Lovley, D.R. Stimulating the anaerobic degradation of aromatic hydrocarbons in contaminated sediments by providing an electrode as the electron acceptor. Environ. Microbiol. 2010, 12, 1011-1020. [CrossRef] [PubMed]

85. Chen, F.; Li, Z.; Yang, J.; Liang, B.; Huang, C.; Cai, W.; Nan, J.; Wang, A. Electron Fluxes in Biocathode Bioelectrochemical Systems Performing Dechlorination of Chlorinated Aliphatic Hydrocarbons. Front. Microbiol. 2018, 9. [CrossRef] [PubMed]

86. Chen, X.; Liang, P.; Zhang, X.; Huang, X. Bioelectrochemical systems-driven directional ion transport enables low-energy water desalination, pollutant removal, and resource recovery. Bioresour. Technol. 2016, 215, 274-284. [CrossRef] [PubMed]

87. Pous, N.; Koch, C.; Vila-Rovira, A.; Balaguer, M.D.; Colprim, J.; Muhlenberg, J.; Muller, S.; Harnisch, F.; Puig, S. Monitoring and engineering reactor microbiomes of denitrifying bioelectrochemical systems. Rsc Advances 2015, 5, 68326-68333. [CrossRef]

88. Morris, J.M.; Jin, S. Feasibility of using microbial fuel cell technology for bioremediation of hydrocarbons in groundwater. J. Environ. Sci. Health A Tox. Hazard. Subst. Environ. Eng. 2008, 43, 18-23. [CrossRef]

89. Liao, H.; Tang, M.; Luo, L.; Li, C.; Chiclana, F.; Zeng, X.-J. A Bibliometric Analysis and Visualization of Medical Big Data Research. Sustainability 2018, 10, 166. [CrossRef] 
90. Ouyang, W.; Wang, Y.; Lin, C.; He, M.; Hao, F.; Liu, H.; Zhu, W. Heavy metal loss from agricultural watershed to aquatic system: A scientometrics review. Sci. Total. Environ. 2018, 637-638, 208-220. [CrossRef]

91. Chen, C. CiteSpace II: Detecting and visualizing emerging trends and transient patterns in scientific literature. J. Am. Soc. Inf. Sci. Technol. 2006, 57, 359-377. [CrossRef]

92. Han, J.; Teng, X.; Cai, X. A novel network optimization partner selection method based on collaborative and knowledge networks. Inf. Sci. 2019, 484, 269-285. [CrossRef]

93. Yang, L.; Wang, Q.; Bai, X.; Deng, J.; Hu, Y. Mapping of Trace Elements in Coal and Ash Research Based on a Bibliometric Analysis Method Spanning 1971-2017. Minerals 2018, 8, 89. [CrossRef]

94. Lovley, D.R.; Holmes, D.E.; Nevin, K.P. Dissimilatory Fe(III) and Mn(IV) Reduction. Adv. Microb. Physiol. 2004, 49, 219-286. [CrossRef]

95. Long, P.E.; Williams, K.H.; Davis, J.A.; Fox, P.M.; Wilkins, M.J.; Yabusaki, S.B.; Fang, Y.; Waichler, S.R.; Berman, E.S.F.; Gupta, M.; et al. Bicarbonate impact on U(VI) bioreduction in a shallow alluvial aquifer. Geochimica et Cosmochimica Acta 2015, 150, 106-124. [CrossRef]

96. Lovley, D.R.; Phillips, E.J.P.; Gorby, Y.A.; Landa, E.R. Microbial reduction of uranium. Nature 1991, 350, 413-416. [CrossRef]

97. Lovley, D.R. Anaerobic benzene degradation. Biodegradation 2000, 11, 107-116. [CrossRef]

98. Xie, X.; Hu, L.; Pasta, M.; Wells, G.F.; Kong, D.; Criddle, C.S.; Cui, Y. Three-dimensional carbon nanotube-textile anode for high-performance microbial fuel cells. Nano Lett 2011, 11, 291-296. [CrossRef]

99. Cardenas, E.; Wu, W.M.; Leigh, M.B.; Carley, J.; Carroll, S.; Gentry, T.; Luo, J.; Watson, D.; Gu, B.; Ginder-Vogel, M.; et al. Significant association between sulfate-reducing bacteria and uranium-reducing microbial communities as revealed by a combined massively parallel sequencing-indicator species approach. Appl Environ Microbiol 2010, 76, 6778-6786. [CrossRef]

100. Gu, B.H.; Wu, W.M.; Ginder-Vogel, M.A.; Yan, H. Bioreduction of Uranium in a Contaminated Soil. Environ. Sci. Technol. 2005, 39, 4841-4847. [CrossRef]

101. Wu, W.M.; Carley, J.; Fienen, M.; Mehlhorn, T. Pilot-Scale in Situ Bioremediation of Uranium in a Highly Contaminated Aquifer. 1. Conditioning of a Treatment Zone. Environ. Sci. Technol. 2006, 40, 3978-3985. [CrossRef]

102. Wu, W.M.; Carley, J.; Luo, J.; Ginder-Vogel, M.A. In Situ Bioreduction of Uranium (VI) to Submicromolar Levels and Reoxidation by Dissolved Oxygen. Environ. Sci. Technol. 2007, 41, 5716-5723. [CrossRef] [PubMed]

103. Witt, M.E.; Dybas, M.J.; Mark, W.R.; Criddle, C.S. Motility-Enhanced Bioremediation of Carbon Tetrachloride-Contaminated Aquifer Sediments. Environ. Sci. Technol. 1999, 33, 2958-2964. [CrossRef]

104. Aulenta, F.; Majone, M.; Tandoi, V. Enhanced anaerobic bioremediation of chlorinated solvents: environmental factors influencing microbial activity and their relevance under field conditions. J. Chem. Technol. Biotechnol. 2006, 81, 1463-1474. [CrossRef]

105. Aulenta, F.; Tocca, L.; Reale, P.; Rossetti, S.; Majone, M. Bioelectrochemical dechlorination of trichloroethene: From electron transfer mechanisms to process scale-up. J. Biotechnol. 2010, 150, S34-S35. [CrossRef]

106. Aulenta, F.; Tocca, L.; Verdini, R.; Reale, P.; Majone, M. Dechlorination of Trichloroethene in a Continuous-Flow Bioelectrochemical Reactor: Effect of Cathode Potential on Rate, Selectivity, and Electron Transfer Mechanisms. Environ. Sci. Technol. 2011, 45, 8444-8451. [CrossRef] [PubMed]

107. Aulenta, F.; Verdini, R.; Zeppilli, M.; Zanaroli, G.; Fava, F.; Rossetti, S.; Majone, M. Electrochemical stimulation of microbial cis-dichloroethene (cis-DCE) oxidation by an ethene-assimilating culture. New Biotechnol. 2013, 30, 749-755. [CrossRef] [PubMed]

108. Lai, A.; Verdini, R.; Aulenta, F.; Majone, M. Influence of nitrate and sulfate reduction in the bioelectrochemically assisted dechlorination of cis-DCE. Chemosphere 2015, 125, 147-154. [CrossRef]

109. Lai, A.; Verdini, R.; Simone, M.; Aulenta, F.; Majone, M. Bioelectrochemical CAHs dechlorination. New Biotechnol. 2016, 33, S132-S133. [CrossRef]

110. Leitao, P.; Rossetti, S.; Danko, A.S.; Nouws, H.; Aulenta, F. Enrichment of Dehalococcoides mccartyi spp. from a municipal activated sludge during AQDS-mediated bioelectrochemical dechlorination of 1,2-dichloroethane to ethene. Bioresour. Technol. 2016, 214, 426-431. [CrossRef]

111. Leitao, P.; Nouws, H.; Danko, A.S.; Aulenta, F. Bioelectrochemical Dechlorination of 1,2-DCAwith an AQDS-Functionalized Cathode Serving as Electron Donor. Fuel Cells 2017, 17, 612-617. [CrossRef] 
112. Leitao, P.; Rossetti, S.; Nouws, H.P.A.; Danko, A.S.; Majone, M.; Aulenta, F. Bioelectrochemically-assisted reductive dechlorination of 1,2-dichloroethane by a Dehalococcoides-enriched microbial culture. Bioresour. Technol. 2015, 195, 78-82. [CrossRef] [PubMed]

113. Palma, E.; Daghio, M.; Tofalos, A.E.; Franzetti, A.; Viggi, C.C.; Fazi, S.; Papini, M.P.; Aulenta, F. Anaerobic electrogenic oxidation of toluene in a continuous-flow bioelectrochemical reactor: process performance, microbial community analysis, and biodegradation pathways. Environ. Sci-Water Res. Technol. 2018, 4, 2136-2145. [CrossRef]

114. Verdini, R.; Aulenta, F.; de Tora, F.; Lai, A.; Majone, M. Relative contribution of set cathode potential and external mass transport on TCE dechlorination in a continuous-flow bioelectrochemical reactor. Chemosphere 2015, 136, 72-78. [CrossRef] [PubMed]

115. Zhao, Y.; Feng, C.; Wang, Q.; Yang, Y.; Zhang, Z.; Sugiura, N. Nitrate removal from groundwater by cooperating heterotrophic with autotrophic denitrification in a biofilm-electrode reactor. J. Hazard. Mater. 2011, 192, 1033-1039. [CrossRef] [PubMed]

116. Zhao, Y.; Zhang, B.; Feng, C.; Huang, F.; Zhang, P.; Zhang, Z.; Yang, Y.; Sugiura, N. Behavior of autotrophic denitrification and heterotrophic denitrification in an intensified biofilm-electrode reactor for nitrate-contaminated drinking water treatment. Bioresour. Technol. 2012, 107, 159-165. [CrossRef]

117. Hao, L.; Zhang, B.; Cheng, M.; Feng, C. Effects of various organic carbon sources on simultaneous V(V) reduction and bioelectricity generation in single chamber microbial fuel cells. Bioresour. Technol. 2016, 201, 105-110. [CrossRef]

118. Zhang, B.; Liu, Y.; Tong, S.; Zheng, M.; Zhao, Y.; Tian, C.; Liu, H.; Feng, C. Enhancement of bacterial denitrification for nitrate removal in groundwater with electrical stimulation from microbial fuel cells. J. Power Sources 2014, 268, 423-429. [CrossRef]

119. Tong, S.; Zhang, B.; Feng, C.; Zhao, Y.; Chen, N.; Hao, C.; Pu, J.; Zhao, L. Characteristics of heterotrophic/biofilm-electrode autotrophic denitrification for nitrate removal from groundwater. Bioresour. Technol. 2013, 148, 121-127. [CrossRef]

120. Wang, Z.; Zhang, B.G.; Borthwick, A.G.L.; Feng, C.P. Utilization of single-chamber microbial fuel cells as renewable power sources for electrochemical degradation of nitrogen-containing organic compounds. Chem. Eng. J. 2015, 280, 99-105. [CrossRef]

121. Zhang, B.; Wang, Z.; Zhou, X.; Shi, C.; Guo, H.; Feng, C. Electrochemical decolorization of methyl orange powered by bioelectricity from single-chamber microbial fuel cells. Bioresour. Technol. 2015, 181, 360-362. [CrossRef]

122. Lloyd, J.R.; Renshaw, J.C. Bioremediation of radioactive waste: radionuclide-microbe interactions in laboratory and field-scale studies. Curr. Opin. Biotechnol. 2005, 16, 254-260. [CrossRef] [PubMed]

123. Morris, K.; Livens, F.R.; Charnock, J.M.; Burke, I.T.; McBeth, J.M.; Begg, J.D.C.; Boothman, C.; Lloyd, J.R. An X-ray absorption study of the fate of technetium in reduced and reoxidised sediments and mineral phases. Appl. Geochem. 2008, 23, 603-617. [CrossRef]

124. Burke, I.T.; Boothman, C.; Lloyd, J.R.; MORTIMER, R.J.G. Effects of Progressive Anoxia on the Solubility of Technetium in Sediments. Environ. Sci. Technol. 2005, 39, 4109-4116. [CrossRef] [PubMed]

125. Thorpe, C.L.; Law, G.T.W.; Lloyd, J.R.; Williams, H.A.; Atherton, N.; Morris, K. Quantifying Technetium and Strontium Bioremediation Potential in Flowing Sediment Columns. Environ. Sci. Technol. 2017, 51, 12104-12113. [CrossRef] [PubMed]

126. Molognoni, D.; Devecseri, M.; Cecconet, D.; Capodaglio, A.G. Cathodic groundwater denitrification with a bioelectrochemical system. J. Water Process Eng. 2017, 19, 67-73. [CrossRef]

127. Cecconet, D.; Bolognesi, S.; Callegari, A.; Capodaglio, A.G. Controlled sequential biocathodic denitrification for contaminated groundwater bioremediation. Sci. Total. Environ. 2019, 651, 3107-3116. [CrossRef] [PubMed]

128. Cecconet, D.; Bolognesi, S.; Molognoni, D.; Callegari, A.; Capodaglio, A.G. Influence of reactor's hydrodynamics on the performance of microbial fuel cells. J. Water Process Eng. 2018, 26, 281-288. [CrossRef]

129. Capodaglio, A.G.; Cecconet, D.; Molognoni, D. An Integrated Mathematical Model of Microbial Fuel Cell Processes: Bioelectrochemical and Microbiologic Aspects. Processes 2017, 5, 73. [CrossRef]

130. Chen, D.; Yang, K.; Wang, H.; Lv, B. Nitrate removal from groundwater by hydrogen-fed autotrophic denitrification in a bio-ceramsite reactor. Water Sci. Technol. 2014, 69, 2417-2422. [CrossRef] 
131. Chen, D.; Wang, H.; Ji, B.; Yang, K.; Wei, L.; Jiang, Y. A high-throughput sequencing study of bacterial communities in an autohydrogenotrophic denitrifying bio-ceramsite reactor. Process Biochem. 2015, 50, 1904-1910. [CrossRef]

132. Chen, D.; Wang, H.; Yang, K.; Ma, F. Performance and microbial communities in a combined bioelectrochemical and sulfur autotrophic denitrification system at low temperature. Chemosphere 2018, 193, 337-342. [CrossRef] [PubMed]

133. Chen, D.; Wei, L.; Zou, Z.; Yang, K.; Wang, H. Bacterial communities in a novel three-dimensional bioelectrochemical denitrification system: the effects of pH. Appl. Microbiol. Biotechnol. 2016, 100, 6805-6813. [CrossRef] [PubMed]

134. Holmes, D.E.; Finneran, K.T.; O’Neil, R.A.; Lovley, D.R. Enrichment of members of the family Geobacteraceae associated with stimulation of dissimilatory metal reduction in uranium-contaminated aquifer sediments. Appl.Environ. Microbiol. 2002, 68, 2300-2306. [CrossRef] [PubMed]

135. Choi, B.Y.; Yun, S.T.; Mayer, B.; Kim, K.H. Sources and biogeochemical behavior of nitrate and sulfate in an alluvial aquifer: hydrochemical and stable isotope approaches. Appl. Geochem. 2011, 26, 1249-1260. [CrossRef]

136. Kumar, N.; Couture, R.M.; Millot, R.; Battaglia-Brunet, F.; Rose, J. Microbial Sulfate Reduction Enhances Arsenic Mobility Downstream of Zerovalent-Iron-Based Permeable Reactive Barrier. Environ. Sci. Technol. 2016, 50, 7610-7617. [CrossRef]

137. Van Khanh, N.; Park, Y.; Yang, H.; Yu, J.; Lee, T. Effect of the cathode potential and sulfate ions on nitrate reduction in a microbial electrochemical denitrification system. J. Ind. Microbiol. Biotechnol. 2016, 43, 783-793. [CrossRef]

138. Florez, C.; Park, Y.; Valles-Rosales, D.; Lara, A.; Rivera, E. Removal of Uranium from Contaminated Water by Clay Ceramics in Flow-Through Columns. Water 2017, 9, 761. [CrossRef]

139. Pous, N.; Koch, C.; Colprim, J.; Puig, S.; Harnisch, F. Extracellular electron transfer of biocathodes: Revealing the potentials for nitrate and nitrite reduction of denitrifying microbiomes dominated by Thiobacillus sp. Electrochem. Commun. 2014, 49, 93-97. [CrossRef]

140. Reguera, G.; McCarthy, K.D.; Mehta, T.; Nicoll, J.S.; Tuominen, M.T.; Lovley, D.R. Extracellular electron transfer via microbial nanowires. Nature 2005, 435, 1098-1101. [CrossRef]

141. Gregory, K.B.; Bond, D.R.; Lovley, D.R. Graphite electrodes as electron donors for anaerobic respiration. Environ. Microbiol. 2004, 6, 596-604. [CrossRef]

142. Gregory, K.B.; Lovley, D.R. Remediation and recovery of uranium from contaminanted subsurface environments with electrodes. Environ. Sci. Technol. 2005, 39, 8943-8947. [CrossRef] [PubMed]

143. Winderl, C.; Anneser, B.; Griebler, C.; Meckenstock, R.U.; Lueders, T. Depth-resolved quantification of anaerobic toluene degraders and aquifer microbial community patterns in distinct redox zones of a tar oil contaminant plume. Appl. Environ. Microbiol. 2008, 74, 792-801. [CrossRef] [PubMed]

144. Davis, J.B.; Yarbrough, H.F. Preliminary Experiments on a Microbial Fuel Cell. Science 1962, 137, $615-616$. [CrossRef] [PubMed]

145. Puig, S.; Coma, M.; Desloover, J.; Boon, N.; Colprim, J.; Balaguer, M.D. Autotrophic Denitrification in Microbial Fuel Cells Treating Low Ionic Strength Waters. Environ. Sci. Technol. 2012, 46, 2309-2315. [CrossRef] [PubMed]

146. Zou, S.; Guan, L.; Taylor, D.P.; Kuhn, D.; He, Z. Nitrogen removal from water of recirculating aquaculture system by a microbial fuel cell. Aquaculture 2018, 497, 74-81. [CrossRef]

147. Vrionis, H.A.; Anderson, R.T.; Ortiz-Bernad, I.; O’Neill, K.R.; Resch, C.T.; Peacock, A.D.; Dayvault, R.; White, D.C.; Long, P.E.; Lovley, D.R. Microbiological and geochemical heterogeneity in an in situ uranium bioremediation field site. Appl. Environ. Microbiol. 2005, 71, 6308-6318. [CrossRef] [PubMed]

148. Rooney-varga, J.; Anderson, R.T.; Fraga, J.; Ringelberg, D. Microbial Communities Associated with Anaerobic Benzene Degradation in a Petroleum Contaminated Aquifer. Appl. Environ. Microbiol. 1999, 65, 3056-3063.

149. Harrison, I.; Williams, G.; Higgo, J.; Leader, R. Microcosm studies of microbial degradation in a coal tar distillate plume. J. Contam. Hydrol. 2001, 53, 319-340. [CrossRef]

150. Gómez, M.A.; Hontoria, E.; González-López, J. Effect of dissolved oxygen concentration on nitrate removal from groundwater using a denitrifying submerged filter. J. Hazard. Mater. 2002, B90, 267-278. [CrossRef] 
151. Tobler, N.B.; Hofstetter, T.B.; Schwarzenbach, R. Carbon and Hydrogen Isotope Fractionation during Anaerobic Toluene Oxidation by Geobacter metallireducens with Different Fe(III) Phases as Terminal Electron Acceptors. Environ. Sci. Technol. 2008, 42, 7786-7792. [CrossRef]

152. Geets, J.; Vanbroekhoven, K.; Borremans, B.; Vangronsveld, J.; Diels, L.; van der Lelie, D. Column experiments to assess the effects of electron donors on the efficiency of in situ precipitation of $\mathrm{Zn}, \mathrm{Cd}, \mathrm{Co}$ and $\mathrm{Ni}$ in contaminated groundwater applying the biological sulfate removal technology. Environ. Sci. Pollut. Res. 2005, 13, 362-378. [CrossRef]

153. Ma, X.; Novak, P.J.; Semmens, M.J.; Clapp, L.W.; Hozalski, R.M. Comparison of pulsed and continuous addition of $\mathrm{H} 2$ gas via membranes for stimulating PCE biodegradation in soil columns. Water Res. 2006, 40, 1155-1166. [CrossRef] [PubMed]

154. Foo, K.Y.; Hameed, B.H. Detoxification of pesticide waste via activated carbon adsorption process. J. Hazard. Mater. 2010, 175, 1-11. [CrossRef] [PubMed]

155. Feleke, Z.; Sakakibara, Y. A bio-electrochemical reactor coupled with adsorber for the removal of nitrate and inhibitory pesticide. Water Res. 2002, 36, 3092-3102. [CrossRef]

156. Nguyen, V.K.; Park, Y.; Yu, J.; Lee, T. Bioelectrochemical denitrification on biocathode buried in simulated aquifer saturated with nitrate-contaminated groundwater. Environ. Sci. Pollut. Res. 2016, 23, 15443-15451. [CrossRef] [PubMed]

157. Liu, H.; Ramnarayanan, R.; Logan, B.E. Production of Electricity during Wastewater Treatment Using a Single Chamber Microbial Fuel Cell. Environ. Sci. Technol. 2004, 38, 2281-2285. [CrossRef] [PubMed]

158. He, Z.; Minteer, S.D.; Angenent, L.T. Electricity Generation from Artificial Wastewater Using an Upflow Microbial Fuel Cell. Environ. Sci. Technol. 2005, 39, 5262-5267. [CrossRef] [PubMed]

159. Aelterman, P.; Rabaey, K.; Clauwaert, P.; Verstraete, W. Microbial fuel cells for wastewater treatment. Water Sci. Technol. 2006, 54, 9-15. [CrossRef]

160. Capodaglio, A.G.; Molognoni, D.; Puig, S.; Balaguer, M.D.; Colprim, J. Role of Operating Conditions on Energetic Pathways in a Microbial Fuel Cell. Energy Procedia 2015, 74, 728-735. [CrossRef]

161. Cheng, S.; Logan, B.E. Ammonia treatment of carbon cloth anodes to enhance power generation of microbial fuel cells. Electrochem. Commun. 2007, 9, 492-496. [CrossRef]

162. Xu, H.; Tong, N.; Huang, S.; Hayat, W.; Fazal, S.; Li, J.; Li, S.; Yan, J.; Zhang, Y. Simultaneous autotrophic removal of sulphate and nitrate at different voltages in a bioelectrochemical reactor (BER): Evaluation of degradation efficiency and characterization of microbial communities. Bioresour. Technol. 2018, 265, 340-348. [CrossRef] [PubMed]

163. Aulenta, F.; Reale, P.; Canosa, A.; Rossetti, S.; Panero, S.; Majone, M. Characterization of an electro-active biocathode capable of dechlorinating trichloroethene and cis-dichloroethene to ethene. Biosens. Bioelectron. 2010, 25, 1796-1802. [CrossRef] [PubMed]

164. Callegari, A.; Cecconet, D.; Molognoni, D.; Capodaglio, A.G. Sustainable processing of dairy wastewater: Long-term pilot application of a bio-electrochemical system. J. Clean Prod. 2018, 189, 563-569. [CrossRef]

165. Clauwaert, P.; Desloover, J.; Shea, C.; Nerenberg, R.; Boon, N.; Verstraete, W. Enhanced nitrogen removal in bio-electrochemical systems by pH control. Biotechnol. Lett. 2009, 31, 1537-1543. [CrossRef] [PubMed]

166. Ng, G.H.; Bekins, B.A.; Cozzarelli, I.M.; Baedecker, M.J.; Bennett, P.C.; Amos, R.T. A mass balance approach to investigating geochemical controls on secondary water quality impacts at a crude oil spill site near Bemidji, MN. J. Contam. Hydrol. 2014, 164, 1-15. [CrossRef] [PubMed]

167. Tong, Y.; He, Z. Nitrate removal from groundwater driven by electricity generation and heterotrophic denitrification in a bioelectrochemical system. J. Hazard. Mater. 2013, 262, 614-619. [CrossRef]

168. Mao, D.; Lu, L.; Revil, A.; Zuo, Y.; Hinton, J.; Ren, Z.J. Geophysical Monitoring of Hydrocarbon-Contaminated Soils Remediated with a Bioelectrochemical System. Environ. Sci. Technol. 2016, 50, 8205-8213. [CrossRef] [PubMed]

169. Yang, Q.; Wang, L.; Ma, H.; Yu, K.; Martin, J.D. Hydrochemical characterization and pollution sources identification of groundwater in Salawusu aquifer system of Ordos Basin, China. Environ. Pollut. 2016, 216, 340-349. [CrossRef] [PubMed]

170. Xie, D.; Yu, H.; Li, C.; Ren, Y.; Wei, C.; Feng, C. Competitive microbial reduction of perchlorate and nitrate with a cathode directly serving as the electron donor. Electrochimica Acta 2014, 133, 217-223. [CrossRef]

171. Kong, X.; Han, Z.; Zhang, W.; Song, L.; Li, H. Synthesis of zeolite-supported microscale zero-valent iron for the removal of $\mathrm{Cr}(6+)$ and $\mathrm{Cd}(2+)$ from aqueous solution. J. Environ. Manage. 2016, 169, 84-90. [CrossRef] 
172. Liu, T.; Yang, X.; Wang, Z.L.; Yan, X. Enhanced chitosan beads-supported Fe(0)-nanoparticles for removal of heavy metals from electroplating wastewater in permeable reactive barriers. Water Res. 2013, 47, 6691-6700. [CrossRef] [PubMed]

173. Kokabian, B.; Gude, V.G. Biodiesel produced wastewater treatment combined with desalination in bioelectrochemical systems. Abstracts of Papers of the American Chemical Society 2013, 245.

174. Morris, J.M.; Jin, S.; Crimi, B.; Pruden, A. Microbial fuel cell in enhancing anaerobic biodegradation of diesel. Chem. Eng. J. 2009, 146, 161-167. [CrossRef]

175. Feleke, Z.; Sakakibara, Y. Nitrate and pesticide removal by a combined bioelectrochemical/adsorption process. Water Sci. Technol. 2001, 43, 25-33. [CrossRef] [PubMed]

176. Obiri-Nyarko, F.; Grajales-Mesa, S.J.; Malina, G. An overview of permeable reactive barriers for in situ sustainable groundwater remediation. Chemosphere 2014, 111, 243-259. [CrossRef] [PubMed]

177. Huang, B.; Feng, H.; Wang, M.; Li, N.; Cong, Y.; Shen, D. The effect of C/N ratio on nitrogen removal in a bioelectrochemical system. Bioresour. Technol. 2013, 132, 91-98. [CrossRef]

(C) 2019 by the authors. Licensee MDPI, Basel, Switzerland. This article is an open access article distributed under the terms and conditions of the Creative Commons Attribution (CC BY) license (http://creativecommons.org/licenses/by/4.0/). 